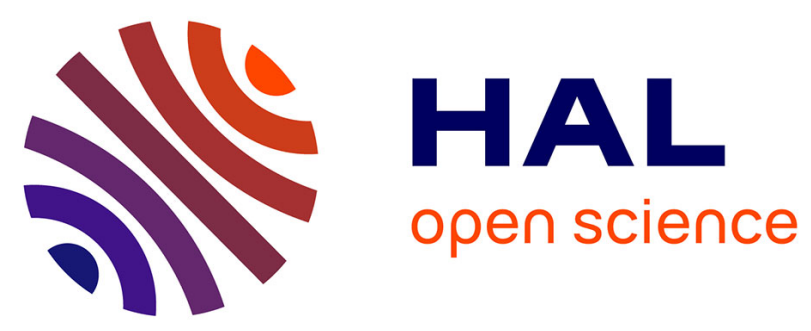

\title{
Caribbean intra-plate deformation: Paleomagnetic evidence from St. Barthélemy Island for post-Oligocene rotation in the Lesser Antilles forearc
}

Mélody Philippon, Douwe J.J. van Hinsbergen, Lydian M Boschman, Lidewij A.W. Gossink, Jean-Jacques Cornée, Marcelle Boudagher-Fadel, Jean-Len Léticée, Jean-Frederic Lebrun, Philippe Munch

\section{To cite this version:}

Mélody Philippon, Douwe J.J. van Hinsbergen, Lydian M Boschman, Lidewij A.W. Gossink, JeanJacques Cornée, et al.. Caribbean intra-plate deformation: Paleomagnetic evidence from St. Barthélemy Island for post-Oligocene rotation in the Lesser Antilles forearc. Tectonophysics, 2020, 777, pp.228323. 10.1016/j.tecto.2020.228323 . hal-03005787

\section{HAL Id: hal-03005787 https://hal.science/hal-03005787}

Submitted on 14 Nov 2020

HAL is a multi-disciplinary open access archive for the deposit and dissemination of scientific research documents, whether they are published or not. The documents may come from teaching and research institutions in France or abroad, or from public or private research centers.
L'archive ouverte pluridisciplinaire HAL, est destinée au dépôt et à la diffusion de documents scientifiques de niveau recherche, publiés ou non, émanant des établissements d'enseignement et de recherche français ou étrangers, des laboratoires publics ou privés. 


\title{
Caribbean intra-plate deformation: Paleomagnetic evidence from St. Barthélemy Island for post-Oligocene rotation in the Lesser Antilles forearc
}

\author{
Mélody Philippon, Douwe J.J. van Hinsbergen, Lydian M. Boschman, Lidewij A.W. Gossink, Jean-Jacques \\ Cornée, Marcelle BouDagher-Fadel, Jean-Len Léticée, Jean-Frederic Lebrun, Philippe Munch \\ Géosciences Montpellier, UMR 5243, CNRS, Université des Antilles-Université de Montpellier, Campus de Fouillole, 97159 Pointe-à-Pitre, FWI, France \\ Department of Earth Sciences, Utrecht University, Princetonlaan 8A, 3584 CD Utrecht, the Netherlands ' ${ }^{c}$ Department of Environmental Systems Science, \\ ETH Zürich, Universitätstrasse 16, 8092 Zürich, Switzerland ${ }^{d}$ Office of the Vice-Provost (Research), 2 Taviton Street, London WC1H 0BT, United Kingdom \\ Géosciences Montpellier, UMR 5243, CNRS_Université des Antilles-Université de Montpellier, Campus du Triolet, 34000 Montpellier, France
}

\section{Introduction}

Classically, the process of subduction is studied in 2D or cylindrical 3D sections with subduction occurring perpendicular to a trench. In reality, however, for instance the subduction of buoyant features, or differential roll-back as a result of slab segmentation, results in trench curvature accommodated by upper plate fragmentation and rotation of upper plate microplates (Vogt et al., 1976; McCabe, 1984; Kissel and Laj, 1988; Calmant et al., 2003; ten Veen and Kleinspehn, 2003; Wallace et al., 2005, 2009; van Hinsbergen et al., 2014, 2020; Legendre et al., 2018), such that's most subduction trenches and are associated with subduction obliquity (e.g., Philippon and Corti, 2016). While the effect of such obliquity, and particularly along-strike changes in obliquity, are not extensively explored yet, preliminary results suggest that these may exert several first-order effects on the subduction system, such as along-strike temperature changes at the plate contact (Plunder et al., 2018), or changes in trench-lateral motion of slabs through the mantle forced by the downgoing plate, i.e. slab dragging (Spakman et al., 2018). Associated with such along-strike changes in obliquity, the upper plate may undergo lateral changes in deformation, in its most pronounced form leading to the formation of forearc slivers that move along the strike of the trench, e.g. from Sumatra to Myanmar (e.g., Curray, 2005; Bradley et al., 2017).

A pronounced curved trench is present in the northeastern Caribbean region. There, a N-S trending Lesser Antilles trench accommodates nearly trench-normal, $\sim 2 \mathrm{~cm} / \mathrm{yr}$ convergence by subduction of Atlantic oceanic lithosphere of the South and North American plates (Pindell and Kennan, 2009; Boschman et al., 2014). To the north, this trench curves to an almost E-W orientation towards the northern Caribbean transform plate boundary between the Caribbean and North American plates. This transform plate boundary obliquely cuts across an older, inactive arc preserved in the eastern Greater Antilles block including from west to east: the Gonave, Hispaniola and Puerto-Rico-

Virgin Islands micro-blocks (Fig. 1A). Along the Puerto Rico trench, a

Keywords: Trench curvature Forearc Block rotation

Abstract

As subduction zones and their related processes are often studied in 2D, or cylindrical 3D sections, the dynamic effects of trench curvature and its evolution through time remain

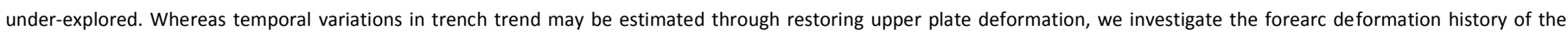

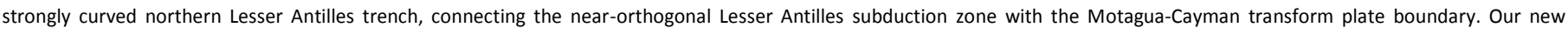

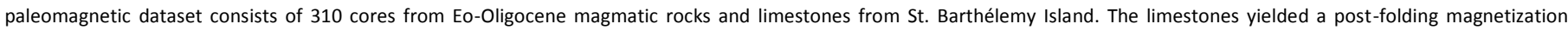

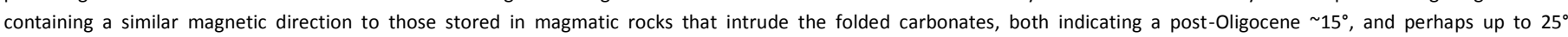

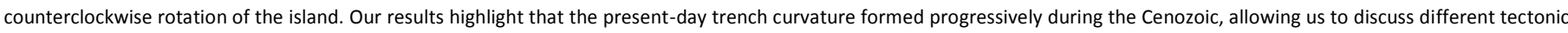

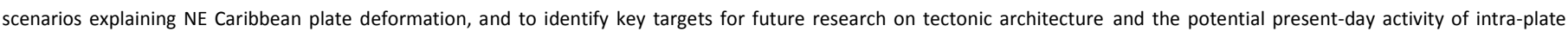
deformation 

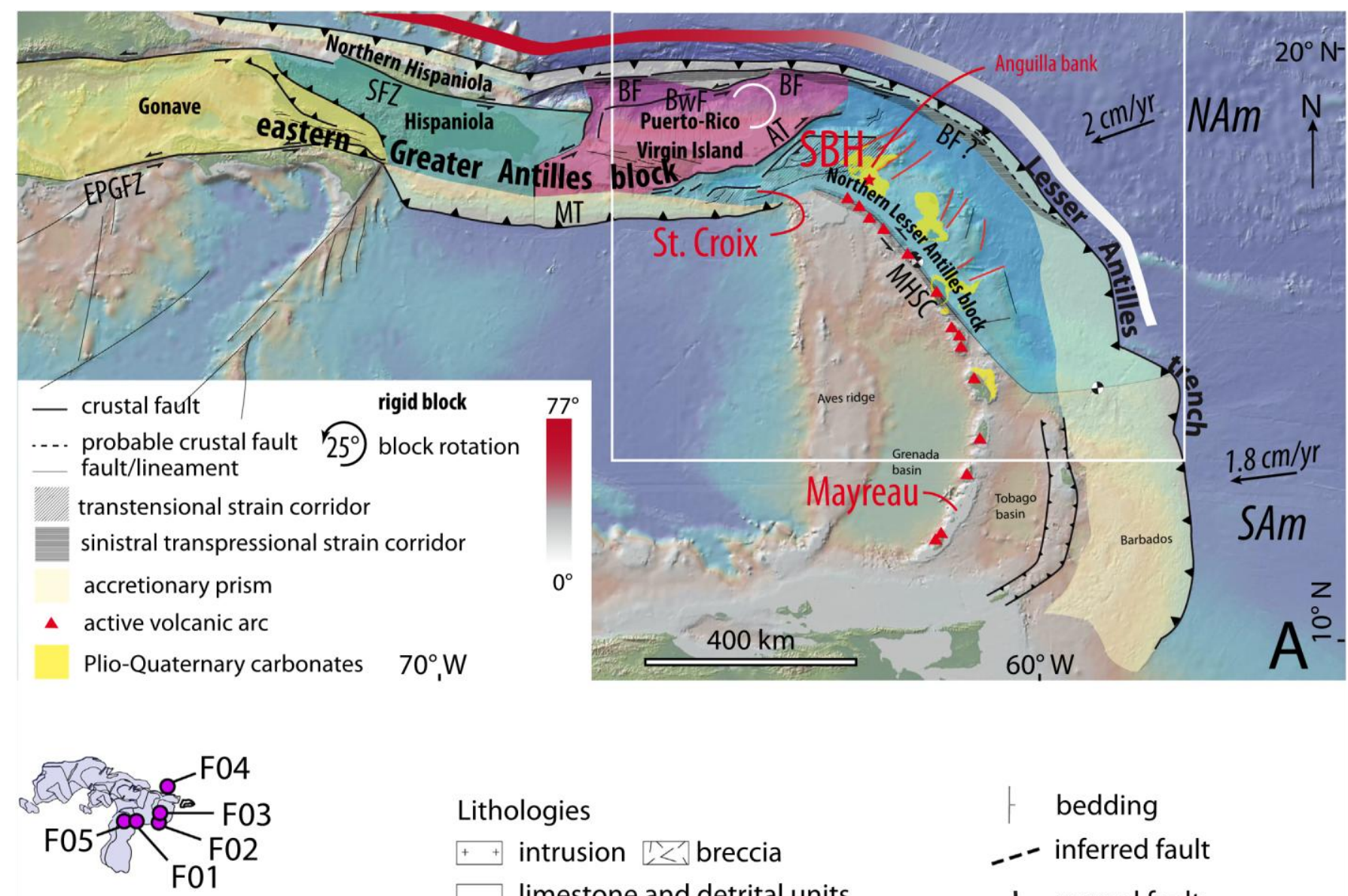

Lithologies

++ intrusion $[\ll]$ breccia

$\square$ limestone and detrital units

a. hyaloclastite

$\checkmark$ lava flow
| bedding

- - inferred fault

$\perp$ normal fault

$\Longleftrightarrow$ strike slip fault

$>$ erosional unconformity

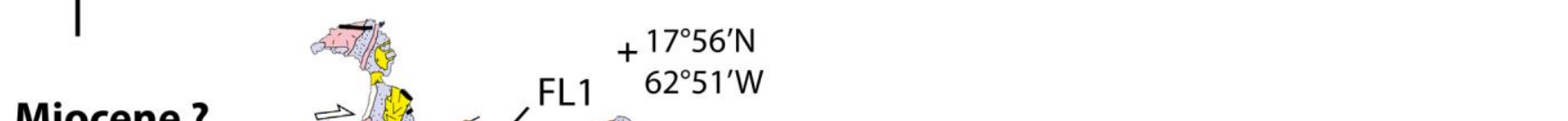

Miocene ?

Oligocene

?

Late Eocene

?

Mid Eocene
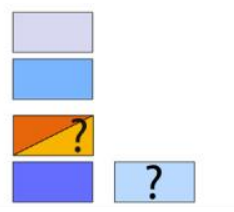
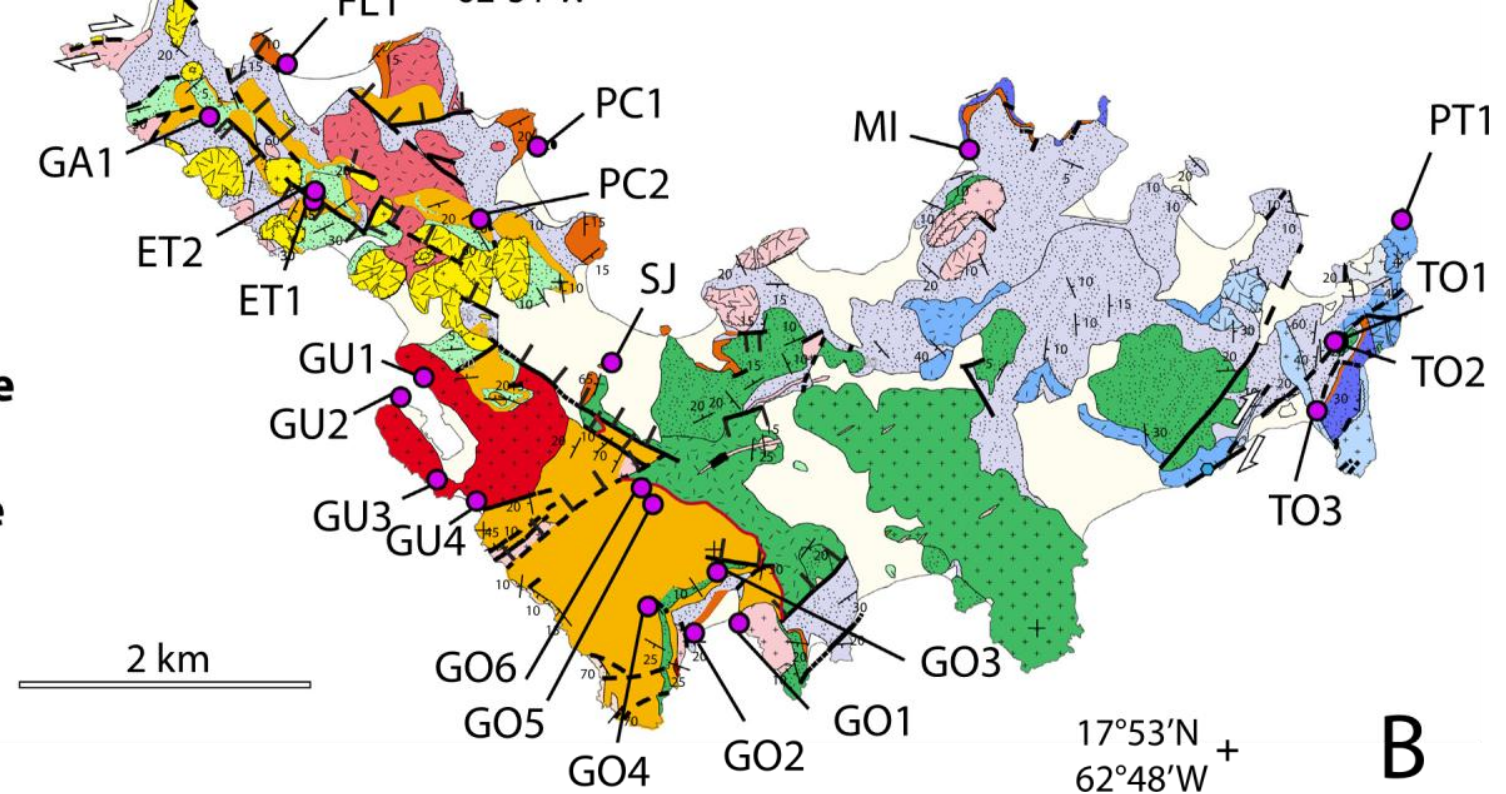

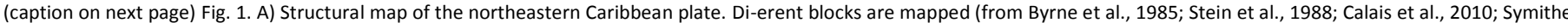

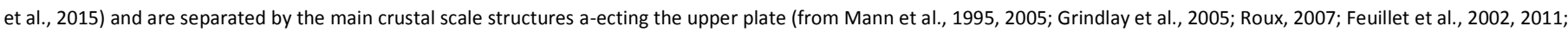

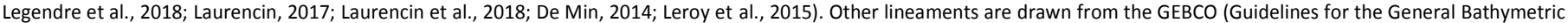




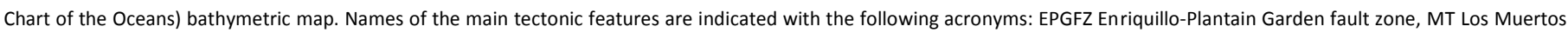

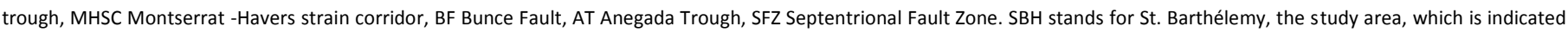
with a red star. B) Geological map of St. Barthélemy Island after Legendre et al. (2018). Purple dots indicate paleomagnetic sampling sites.

south-dipping slab is subducting highly obliquely (almost 80') (Molnar and Sykes, 1971; Stein et al., 1988; Ten Brink et al., 2004; Van Benthem and Govers, 2010, van Benthem et al., 2013, 2014; Fig. 1A).

Here, we present paleomagnetic results from Eocene to Oligocene igneous and sedimentary rocks of the island of St. Barthélemy in the northern Lesser Antilles, which is located in the region of maximum trench curvature (Fig. 1). Paleomagnetic research may identify whether vertical axis rotations occurred relative to the main surrounding plates and is thus a good proxy for intra-plate deformation. Paleomagnetic data for the Caribbean region, however, are scarce. Rotations have been reported from the Cretaceous of Cuba (Tait et al., 2009), and the Cretaceous and Cenozoic of Hispaniola (Vincenz and Dasgupta, 1978) and Puerto Rico (Van Fossen et al., 1989; Reid et al., 1991), but those rotations are thought to be representative for pre-Eocene Caribbean plate motion, and Eocene and younger strike-slip related deformation at the northern Caribbean plate boundary zone. Speed et al. (1997) reported paleomagnetic results from the Eocene of Mayreau Island in the south of the Antilles arc that suggested no net rotation relative to the Caribbean plate. From the northeastern Caribbean region, the focus of our study, there are no previous paleomagnetic results. Here we report on an extensive paleomagnetic survey of St. Barthelemy Island, and we use these data to test whether the Antilles trench curvature has been associated from the mid Cenozoic onward by upper plate deformation, and identify possible fault systems that may be responsible for potential rotations.

\section{Tectonic setting}

Plate reconstructions suggest that at least part of the modern curvature of the northern Caribbean region was inherited from Mesozoic plate boundary configurations, but part of it may be much younger, and is perhaps even actively forming today. The geometry of the Caribbean plate results from a long-term evolution that started with the split from the Farallon plate during the Late Cretaceous (Pindell and Kennan, 2009; Whattam and Stern, 2015; Boschman et al., 2019). The Caribbean plate was then captured between the North and South American continents and has been nearly mantle-stationary since 50 Ma (Boschman et al., 2014; Montes et al., 2019a). The Americas moved southwestward, and, since 50 Ma, westward. This 50 Ma switch to westward absolute motion of the Americas coincided with the loss of the "Cuban segment" (Cuba and the Yucatan Basin) through the initiation of the modern northern Caribbean transform plate boundary, where the Cayman Trough started forming around $50 \mathrm{Ma}$ (Leroy et al., 2000). It also coincided with the formation of the modern Antilles trench at the eastern Caribbean plate boundary, most probably initiating along a former transform plate boundary between the Caribbean plate and South America inherited from Late Cretaceous to Paleocene. The present-day overall E-W and N-S trending plate boundary orientations seen in the northeastern Caribbean are thus likely inherited from at least $~ 50 \mathrm{Ma}$ (early Eocene).

During its motion to the west relative to the Caribbean plate, the thick crust underlying the Bahamas platform on the North American plate impinged the northern Caribbean plate at the western extent of the highly oblique northeastern Caribbean subduction zone (LaóDávila, 2014; e.g., van Benthem et al., 2014). This led to strain partitioning between the trench and strike slip faults affecting the Caribbean upper plate, which is manifested by the presence of multiple tectonic microplates in the eastern Greater Antilles block (Byrne et al., 1985; Calais et al., 2010), and perhaps as much as $45^{\circ}$ counterclockwise postEocene rotation of Puerto Rico, which is accommodated at Los Muertos Trough (Fig. 1A, Van Fossen et al., 1989; Reid et al., 1991). This suggests that the modern northeastern Caribbean trench curvature has been modified, and is possibly being modified today, accommodated by upper plate deformation and an associated potential seismic hazard.

Within this framework, we investigated vertical axis rotations recorded by Eocene and younger rocks exposed on St. Barthélemy, which is located in the Lesser Antilles forearc at the northeastern edge of the Caribbean plate. Plate reconstructions place this region adjacent to the southern tip of the Bahamas platform in the Eocene (Boschman et al., 2014; Montes et al., 2019a). We studied the paleomagnetic record in rocks of Eocene and younger age to test for progressive rotation and associated trench curvature (Fig. 1A).

The bathymetry of the northeastern Caribbean plate reveals major scarps and faults that may demonstrate past or present deformation, surrounding apparently less deformed morphologically defined blocks (Fig. 1A). However, estimates of displacement and evidence for the tectonic evolution of these features are sparse and debated. To the northwest, the eastern Greater Antilles block is bounded to the north and south by the sub E-W trending sinistral Septentrional fault zone (SFZ) and Enriquillo-Plantain Garden fault zone (EPGFZ), respectively (Case and Holcombe, 1980). These faults are connected to the Cayman Trough to the west (Leroy et al., 2000). East of the SFZ, CaribbeanNorth America oblique plate motion is accommodated by the Bunce fault (BF), which is a $>500-\mathrm{km}$ long sinistral strike-slip fault located 10-15 km south of the Puerto Rico trench (Ten Brink and Lin, 2004) that likely connects eastward to the Lesser Antilles trench at the latitude of Guadeloupe where subduction obliquity is negligible. In the central part of Hispaniola, the EPGFZ interacts with the E-W Muertos Trough that runs from central Hispaniola to southern St. Croix (Fig. 1A). The Muertos Trough accommodates at least $40 \mathrm{~km}$ crustal scale overthrusting of the Greater Antilles block onto the Caribbean plate interior (i.e., the Venezuelan Basin) (Bruña et al., 2009; Ladd et al., 1977; Byrne et al., 1985; Calais et al., 2016). Along the Muertos Trough, the bulk amount of shortening decreases eastwards towards the Virgin Islands (Masson and Scanlon, 1991; Fig. 1).

To the east, the $450 \mathrm{~km}$ long, NE-SW trending Anegada Trough connects the Bunce Fault to Los Muertos Trough (Fig. 1A). The Anegada Through is thought to have opened under N-S stretching either attributed to the northeastward escape or the counterclockwise rotation of the Puerto Rico Virgin Island block (Jany et al., 1987, 1990; Mauffret and Jany, 1990; Masson and Scanlon, 1991; Laurencin, 2017). The Anegada Trough may have been reactivated during the Pliocene as a strike slip strain corridor, either as left lateral (Mann and Burke, 1984; Raussen et al., 2013; Laurencin, 2017) or right lateral fault (Jany et al., 1987, 1990; Mauffret and Jany, 1990). Others interpreted Anegada Trough opening as due to trench-parallel stretching accommodating trench curvature that triggered radial extension in the upper plate (Speed and Larue, 1991; Feuillet et al., 2002). At the southwestern end of the Anegada Trough, the Muertos Trough connects with the Montserrat-Havers Strain Corridor (MHSC), which is an "en-échelon" sinistral strike slip fault defining a NNW-SSE trending strain corridor located along the volcanic arc of the Lesser Antilles subduction zone (Fig. 1A, MHSC) (Feuillet et al., 2002; Feuillet et al., 2011; Kenedi et al., 2010; Baird et al., 2015). 
Southeast of the Anegada Trough, a Northern Lesser Antilles block may be bounded by the MHSC to the west and the Bunce Fault-Lesser Antilles trench to the East (Feuillet et al., 2002; López et al., 2006), though its presence is not required by the currently available GPS data in this region (Symithe et al., 2015). The northern part of the Lesser Antilles forearc is distinct from the southern one in that (i) seismic activity is higher (Dorel, 1981); (ii) it exposes Eocene to lower Miocene volcanic arc rocks and overlying platforms instead of only upper Miocene and younger rocks (Fig. 1B) (Bouysse and Westercamp, 1990); (iii) it contains large and deep (tens of km length and 3-5 km depth) trenchnormal V-shaped basins bounded by steep, crustal normal faults possibly reflecting radial extension whose age is not definitely established (Red fault in Fig. 1A, Feuillet et al., 2002; Roux, 2007; De Min et al., 2015); and (iv) Plio - Quaternary carbonate platforms covering/sealing E-W to NE-SW trending large normal faults are present (e.g., the northwestern edge of the Anguilla bank, the La Désirade Wall bounding the island to the north) (Bouysse and Westercamp, 1990; Feuillet et al., 2002, 2011) (Fig. 1A).

The island of St. Barthélemy is located in the Northern part of the Northern Lesser Antilles block and exposes mid-Eocene to lower Miocene volcanic rocks interbedded with limestones (Legendre et al., 2018). The island shows a regional bedding trending sub E-W and dipping to the south and is affected by series of N50 and N140 large transtensional faults that locally re-orient the regional bedding. St. Barthélemy is the southernmost island of the Anguilla bank. A NE-SW dextral strike slip corridor, parallel to the SE border of the bank, affects the eastern part of the island and has been dated as post-mid Eocene (Legendre et al., 2018) (Fig. 1B). The island exposes rocks that were formed contemporaneously with the major switch in absolute American plate motion and the subsequent plate reorganization. It is thus a strategic target for a paleomagnetic study to evidence potential post mid-Eocene rotations east of the Puerto-Rico-Virgin Islands (PRVI) and the Anegada Trough, and potentially shed light on the large-scale Lesser Antillean forearc deformation.

\section{Paleomagnetic sampling and methods}

We sampled a total of 310 paleomagnetic cores, $2.5 \mathrm{~cm}$ in diameter, at 27 sampling locations across St. Barthélemy Island and the neighboring uninhabited islet, île Fourchue (Fig. 1B). Samples were drilled with a gasoline-powered motor drill, and oriented with an ASC-OR2 orientation device and a Brunton compass. Sites are located around the capital Gustavia (GU), at the north and northwestern part of the island (ET, PC, FL, GA, MI, SJ), at Governor Beach (GO), at the eastern part of the island (PT, TO) and île Fourchue (FO) (Fig. 1B). Lithologies and ages vary: we sampled folded and thrusted mid to upper Eocene limestones (TO1-3, GO2-6, GA1, ET1-2, FL1, SJ1, MI1, PC2). These are wellbedded with bedding dips sufficiently different to allow for a regional fold test to evaluate the pre- or post-folding age of the magnetization. These Eocene limestones were, after folding and thrusting, intruded by mid-Eocene ( $\sim 40-35 \mathrm{Ma}$ ) and Oligocene (26-24 Ma) shallow igneous intrusions ( $\mathrm{Ar}_{39} / \mathrm{Ar}_{40}$ dating on plagioclases or groundmass, Legendre et al., 2018; Cornée et al., 2020). From these igneous intrusions, no bedding can be obtained and we only interpret the paleomagnetic directions in situ and discuss the likelihood of significant tilt in the discussion section. From Eocene igneous intrusions on St Barthelemy, and the nearby islet île Fourchue, we sampled sites (FO1-5, PT1) and from two Oligocene intrusions, we collected sites GO1 and GU1-4 (Fig. 1B). Furthermore, we sampled one lower Miocene (Aquitanian to lower Burdigalian) limestone site (PC1).

Samples were subjected to either stepwise thermal (TH) or alternating field (AF) demagnetization, and natural remanent magnetizations (NRMs) were measured on a 2 G DC SQUID cryogenic magnetometer at the Paleomagnetic Laboratory Fort Hoofddijk, Utrecht University. For TH treatment, we used the following demagnetization steps: $20,100,150{ }^{\circ} \mathrm{C}$ and from 150 to $570^{\circ} \mathrm{C}$ by $30^{\circ} \mathrm{C}$ steps, until complete demagnetization or $570{ }^{\circ} \mathrm{C}$. For $\mathrm{AF}$ treatment, part of the samples was pre-heated to $150^{\circ} \mathrm{C}$ to reduce the effects of weathering on the NRM (e.g., Scheepers and Langereis, 1993), and demagnetization steps used were $0,4,8,12,16,20,25,30,35,40,45,50,60,70$, and $80 \mathrm{mT}$.

Demagnetization data were plotted in orthogonal vector diagrams (Zijderveld, 1967), and the Characteristic Remanent Magnetization (ChRM) was determined via principal component analysis (Kirschvink, 1980). We calculated site mean directions using Fisher (1953) statistics on virtual magnetic poles (VGPs) and applied a $45^{\circ}$ cut-off to the VGPs when interpreting average directions (Johnson et al., 2008). We calculated declination and inclination errors $\Delta \mathrm{D}_{\mathrm{x}}$ and $\Delta \mathrm{I}_{\mathrm{x}}$ following Butler (1992) and Deenen et al. (2011). We followed the statistical approach of Deenen et al. (2011) and calculated the mean paleomagnetic direction by calculating the virtual geomagnetic pole of each measured ChRM direction of all samples from the different sites, and compute one grand mean based on all data. This approach assumes that each ChRM direction represents a spot reading of the magnetic field, which is typically justified for sedimentary or intrusive rocks (for lavas, each flow unit gives one spot reading of the magnetic field, no matter how many samples are taken from that lava). The assumption that the ChRM population represents independent readings of paleosecular variation may be evaluated using the $n$-dependent confidence envelope of Deenen et al. (2011) (A95min < A95 < A95max) which tests whether the A95 cone of confidence of a dataset may be straightforwardly explained by paleosecular variation. Classically, paleomagnetists calculate the average pole based on site averages, ignoring the uncertainty and difference in sample size. Using this approach yields a statistically indistinguishable direction, but with larger error bar due to the artificially lower $\mathrm{n}$. For reference, we added averages based on site averages to Table 1, and briefly address whether there are significant differences between the approaches in the text. We used the fold test of Tauxe and Watson (1994) and the reversal test of Tauxe (2010). Data have been corrected for a local declination of $14^{\circ} \mathrm{W}$. Laboratory analyses were carried out at Paleomagnetic Laboratory Fort Hoofddijk at Utrecht University in the Netherlands, and for data visualization, interpretation, and statistical analysis, the online portal paleomagnetism.org (Koymans et al., 2016) was used. All data and interpretations are provided in the supplementary information.

\section{Paleomagnetic results}

\subsection{Limestones (ET1-2, FL1, GA1, GO2-6, MI1, PC1-2, SJ1, TO1-3)}

Initial intensities from the limestone samples range from 0.05 to $15 \mathrm{~mA} / \mathrm{m}$. For sites GA1, GO2-6, ET1-2, SJ1, MI1, and PC1-2, ChRM directions were typically interpreted in the range of $240-480{ }^{\circ} \mathrm{C}$ or $25-70 \mathrm{mT}$, and for sites FL1 and TO1-3, in the range of $390-570{ }^{\circ} \mathrm{C}$ or $35-80 \mathrm{mT}$. The thermal demagnetization behavior typically shows demagnetization until $480-570{ }^{\circ} \mathrm{C}$ suggesting that these components are carried by magnetite or titanomagnetite. Particularly the thermally demagnetized samples reveal a reversed polarity in the higher temperature ranges $\left(400-570^{\circ} \mathrm{C}\right)$, which we interpreted as the Characteristic Remanent Magnetization (Fig. 2-a).

Most samples contain a normal overprint consistent with the recent field (Fig. 2-b), or a normal direction that appears to be antipodal to the reversed component (Fig. 2-c). AF demagnetized samples more or less simultaneously unblock both components (Fig. 2-d) leading to great circle trajectories that we 
used to determine the plane within which the ChRM is interpreted to be located (Fig. 2-e). These were used in combination with set points derived from samples in which a ChRM was isolated to determine a most likely ChRM (McFadden and McElhinny, 1988) (Fig. 2-f; all demagnetization diagrams and interpretations are provided in the Supplementary Information).

In some cases, the reversed polarity component does not converge to the origin, and a high-coercivity normal component remains undemagnetized, which

Table 1

Paleomagnetic results from St. Barthélemy. Lat $=$ Latitude; Lon = Longitude; $\mathrm{Nd}=$ number of demagnetized specimens; $\mathrm{Ni}=$ number of interpreted ChRM directions; $\mathrm{N} 45=\mathrm{Number}$ of directions that pass the $45^{\circ}$ cutoff; $P=$ Polarity; $D=$ Declination, $\Delta D x=$ Error on declination following Butler, 1992; I = Inclination; $\Delta \mathrm{lx}=$ Error on inclination following Butler, $1992 ;$ a95 = cone of confidence assuming Fisherian distribution of paleomagnetic directions; $\mathrm{k}=$ Fisher (1953) precision assuming Fisherian distribution of paleomagnetic directions; $\mathrm{A} 95$ = cone of

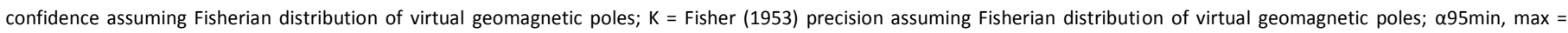
Deenen et al. (2011) $n$-dependent reliability envelope; $\lambda=$ paleolatitude.

\begin{tabular}{|c|c|c|c|c|c|c|c|c|c|c|c|c|c|c|c|c|c|c|c|c|c|c|}
\hline \multirow[b]{2}{*}{ Site name } & \multirow[b]{2}{*}{ Lat $\left({ }^{\circ} \mathrm{N}\right)$} & \multirow[b]{2}{*}{ Lon $\left({ }^{\circ} \mathrm{W}\right)$} & \multirow[b]{2}{*}{$\mathrm{Nd}$} & \multirow[b]{2}{*}{$\mathrm{Ni}$} & \multirow[b]{2}{*}{$\mathrm{N} 45$} & \multirow[b]{2}{*}{ Pol } & \multicolumn{4}{|c|}{ Geographic } & \multicolumn{4}{|c|}{ Tectonic } & \multirow[b]{2}{*}{$\alpha 95$} & \multirow[b]{2}{*}{ k } & \multirow[b]{2}{*}{ A95 } & \multirow[b]{2}{*}{$\mathrm{K}$} & \multirow[b]{2}{*}{ A95min } & \multirow[b]{2}{*}{ A95max } & \multirow[b]{2}{*}{$\lambda\left({ }^{\circ} \mathrm{N}\right)[\mathrm{min}, \max ]$} & \multirow[b]{2}{*}{ Bedding } \\
\hline & & & & & & & D & $\Delta \mathrm{Dx}$ & 1 & $\Delta \mathrm{lx}$ & $\mathrm{D}$ & $\Delta \mathrm{Dx}$ & 1 & $\Delta \mathrm{lx}$ & & & & & & & & \\
\hline \multicolumn{23}{|c|}{ Middle Eocene limestones } \\
\hline ET1 & 17.9115 & 62.8586 & 7 & 7 & 7 & $\mathbf{R}$ & 161.0 & 4.4 & -11.5 & 8.5 & 168.0 & 4.7 & -19.5 & 8.4 & 5.5 & 119.8 & 4.4 & 191.5 & 5.5 & 24.1 & & $002 / 26$ \\
\hline ET2 & 17.9115 & 62.8584 & 7 & 6 & 6 & $\mathrm{R}$ & 161.9 & 2.8 & -10.9 & 5.5 & 164.4 & 2.7 & 6.3 & 5.3 & 3.5 & 375.0 & 2.8 & 569.1 & 5.9 & 26.5 & & $328 / 60$ \\
\hline FL1 & 17.9201 & 62.8602 & 10 & 10 & 8 & $\mathrm{R}$ & 150.4 & 15.2 & -17.3 & 28.1 & 141.0 & 17.1 & -11.0 & 33.1 & 16.5 & 12.2 & 15.0 & 14.5 & 5.2 & 22.1 & & $168 / 16$ \\
\hline GA1 & 17.9169 & 62.8649 & 6 & 6 & 6 & $\mathrm{~N}$ & 54.4 & 18.5 & 1.7 & 37.1 & 54.4 & 18.5 & 5.7 & 36.6 & 25.7 & 7.8 & 18.5 & 14.0 & 5.9 & 26.5 & & $146 / 4$ \\
\hline GO2 & 17.8843 & 62.8342 & 7 & 7 & 7 & $\mathrm{R}$ & 152.3 & 13.0 & -28.3 & 20.8 & 152.3 & 13.0 & -28.3 & 20.8 & 13.8 & 20.2 & 12.5 & 24.2 & 5.5 & 24.1 & & $107 / 13$ \\
\hline GO3 & 17.8881 & 62.8328 & 7 & 6 & 6 & $\mathrm{R}$ & 172.1 & 14.2 & -14.7 & 26.7 & 168.5 & 15.2 & -26.5 & 25.0 & 20.0 & 12.2 & 14.0 & 23.8 & 5.9 & 26.5 & & $119 / 15$ \\
\hline GO4 & 17.8859 & 62.8372 & 7 & 6 & 6 & $\mathrm{R}$ & 164.1 & 13.0 & -2.9 & 26.0 & 163.2 & 12.9 & -9.0 & 25.2 & 14.0 & 23.7 & 13.0 & 27.3 & 5.9 & 26.5 & & $126 / 10$ \\
\hline GO5 & 17.8924 & 62.8369 & 7 & 6 & 6 & $\mathrm{R}$ & 157.3 & 9.3 & -14.3 & 17.6 & 159.9 & 9.6 & -19.0 & 17.3 & 11.0 & 38.1 & 9.2 & 54.0 & 5.9 & 26.5 & & 010/07 \\
\hline GO6 & 17.8933 & 62.8374 & 6 & 5 & 5 & $\mathrm{R}$ & 155.0 & 8.9 & -12.8 & 17.1 & 155.6 & 8.6 & -5.6 & 17.1 & 9.4 & 67.4 & 8.9 & 75.1 & 6.3 & 29.7 & & $271 / 8$ \\
\hline MI1 & 17.9146 & 62.8167 & 10 & 9 & 9 & $\mathrm{~N}$ & 333.1 & 6.5 & 15.0 & 12.2 & 334.5 & 7.2 & 30.6 & 11.2 & 8.5 & 37.8 & 6.4 & 64.9 & 5.0 & 20.5 & & $52 / 16$ \\
\hline PC2 & 17.9102 & 62.8478 & 9 & 5 & 5 & $\mathrm{R}$ & 149.5 & 4.0 & -6.2 & 8.0 & 151.4 & 4.4 & -25.0 & 7.3 & 5.4 & 200.3 & 4.0 & 363.8 & 6.3 & 29.7 & & $41 / 20$ \\
\hline SJ1 & 17.9012 & 62.8394 & 6 & 4 & 4 & $\mathrm{R}$ & 139.1 & 13.8 & 16.5 & 25.6 & 160.1 & 10.6 & 23.1 & 18.4 & 13.6 & 46.5 & 13.6 & 46.4 & 6.9 & 34.2 & & $156 / 54$ \\
\hline TO1 & 17.9025 & 62.7931 & 6 & 6 & 6 & $\mathrm{R}$ & 149.6 & 10.6 & -21.2 & 18.8 & 149.6 & 10.6 & -21.2 & 18.8 & 14.6 & 21.9 & 10.4 & 42.2 & 5.9 & 26.5 & & $140 / 43$ \\
\hline TO2 & 17.8998 & 62.7943 & 6 & 6 & 6 & $\mathrm{R}$ & 140.0 & 7.8 & -25.1 & 13.1 & 140.8 & 8.7 & 29.2 & 13.8 & 8.2 & 68.5 & 7.6 & 79.5 & 5.9 & 26.5 & & $208 / 58$ \\
\hline TO3 & 17.8982 & 62.7945 & 6 & 5 & 5 & $\mathrm{R}$ & 150.0 & 10.2 & -17.1 & 18.8 & 150.0 & 10.2 & -17.1 & 18.8 & 10.0 & 59.0 & 10.0 & 59.0 & 6.3 & 29.7 & & $26 / 64$ \\
\hline \multicolumn{3}{|c|}{ Average Eocene limestones(directions) } & 94 & 88 & 85 & & 334.9 & 2.8 & 14.0 & 5.3 & 336.2 & 3.6 & 13.5 & 6.8 & 3.4 & 21.1 & 2.8 & 32.1 & 2.0 & 5.0 & $7.1[4.3,9.9]$ & \\
\hline Average Ec & site averag & & 15 & 15 & 14 & & 334.1 & 5.5 & 11.0 & 10.7 & 334.7 & 7.8 & 9.3 & 15.2 & 7.8 & 26.9 & 5.5 & 52.8 & 4.2 & 15.6 & $4.7[-2.9,12.9]$ & \\
\hline Oligocene & & & & & & & & & & & & & & & & & & & & & & \\
\hline GO1 & 17.8849 & 62.8313 & 8 & 8 & 8 & $\mathrm{~N}$ & 337.2 & 7.7 & 33.5 & 11.3 & & & & & 7.2 & 60.4 & 7.3 & 58.3 & 5.2 & 22.1 & & No bedding \\
\hline GU1 & 17.9003 & 62.8514 & 11 & 8 & 8 & $\mathbf{R}$ & 170.9 & 7.6 & -37.7 & 10.3 & & & & & 7.3 & 58.1 & 7.1 & 61.3 & 5.2 & 22.1 & & No bedding \\
\hline GU2 & 17.8990 & 62.8529 & 14 & 6 & 6 & $R$ & 154.6 & 9.6 & -29.2 & 15.1 & & & & & 10.8 & 39.8 & 9.2 & 53.7 & 5.9 & 26.5 & & No bedding \\
\hline GU3 & 17.8940 & 62.8505 & 14 & 8 & 8 & $R$ & 155.2 & 14.0 & -39.2 & 18.1 & & & & & 11.8 & 23.0 & 13.0 & 19.2 & 5.2 & 22.1 & & No bedding \\
\hline GU4 & 17.8926 & 62.8481 & 13 & 8 & 8 & $\mathbf{R}$ & 185.9 & 10.9 & -36.0 & 15.1 & & & & & 13.5 & 17.7 & 10.2 & 30.4 & 5.2 & 22.1 & & No bedding \\
\hline Average $\mathrm{O}$ & rocks/direc & tions) & 60 & 38 & 38 & & 345.0 & 5.4 & 36.0 & 7.4 & & & & & 5.0 & 22.2 & 5.0 & 22.3 & 2.8 & 8.3 & $20.0[15.3,25.4]$ & \\
\hline Average $\mathrm{O}$ & rocks(site a & verages) & 5 & 5 & 5 & & 344.5 & 13.2 & 35.7 & 18.5 & & & & & 11.2 & 48.0 & 12.4 & 38.9 & 6.3 & 29.7 & $19.78[8.8,34.7]$ & \\
\hline Lower Mio & & & & & & & & & & & & & & & & & & & & & & \\
\hline PC1 & 17.9150 & 62.8441 & 7 & 7 & 7 & $\mathrm{R}$ & 163.2 & 13.3 & -9.8 & 26.0 & 167.7 & 13.9 & -22.9 & 24.1 & 14.9 & 17.3 & 13.6 & 20.7 & 5.5 & 24.1 & $12.0[28.2,0.6]$ & $26 / 20$ \\
\hline Eocene plu & & & & & & & & & & & & & & & & & & & & & & \\
\hline FO1 & 17.9554 & -62.9014 & 10 & & & & No mea & aningfu & ul resul & & & & & & & & & & & & & No bedding \\
\hline FO2 & 17.9550 & -62.8994 & 10 & & & & No mea & aningfu & ul resul & & & & & & & & & & & & & No bedding \\
\hline FO3 & 17.9559 & -62.8996 & 10 & & & & No mea & aningfu & ul resul & & & & & & & & & & & & & No bedding \\
\hline FO4 & 17.9581 & -62.8989 & 10 & & & & No mea & aningfu & ul resul & & & & & & & & & & & & & No bedding \\
\hline FO5 & 17.9553 & -63.9025 & 10 & & & & No mea & aningfu & ul resul & & & & & & & & & & & & & No bedding \\
\hline PT1 & 17.9091 & -62.7899 & 23 & & & & No mea & aningfu & ul resul & & & & & & & & & & & & & \\
\hline
\end{tabular}

Orange, Blue and Yellow stand for Middel Eocene, Oligocene and Miocene, respecively. Red indicates the site that recorded a local rotation.

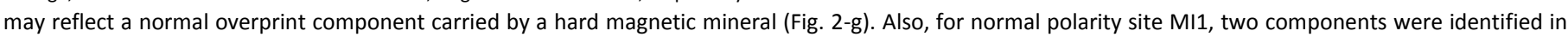

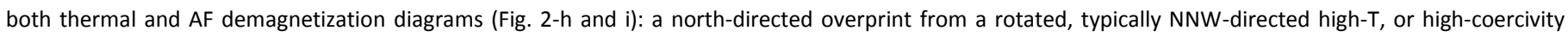

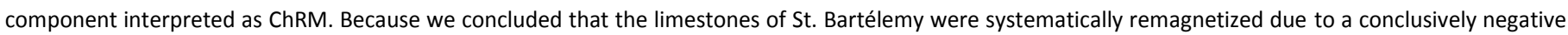

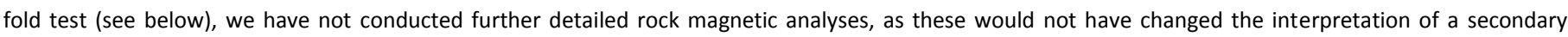

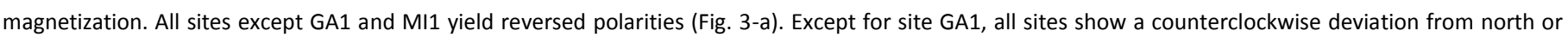

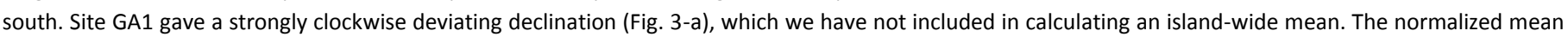
direction of all the Eocene limestone samples in geographic coordinates is: $D \pm \Delta D_{x}=334.9 \pm 2.8^{\circ}, I \pm \Delta I_{x}=14.0 \pm 5.3^{\circ}, n=86, K=32.1, A 95=2.8(F i g .3-b$;

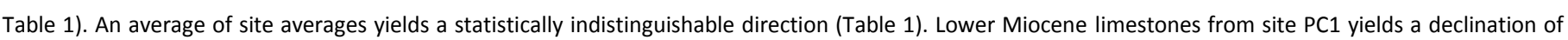
$347.7 \pm 13.9^{\circ}$ in tectonic coordinates, or $343.2 \pm 13.3^{\circ}$ in geographic coordinates $(n=7)($ Table 1$)$.

\subsection{Mid-Eocene intrusive rocks (FO1-5, PT1)}

Initial intensities vary but are mostly very high, up to $50,000 \mathrm{~mA} / \mathrm{m}$, and most demagnetization diagrams show well-defined components decaying towards the origin (Fig. 2-j), or well-defined great circle trajectories. Although well-defined, the directions are strongly scattered, well beyond typical clusters expected from paleo-secular variation (Fig. 2-j). Applying great circle analysis also yielded no meaningful intersection that may reflect a primary magnetization. We interpret these geologically meaningless directions the result of lightning strikes. The sites from île Fourchue were sampled along a high ridge on the northeast coast, where such lightning strikes are not surprising. We have not interpreted a paleomagnetic direction from these Eocene igneous intrusive rocks. 
4.3. Oligocene intrusive rocks (GO1, GU1-4)

Initial intensities for samples from Oligocene igneous intrusions range from 50 to $36,000 \mathrm{~mA} / \mathrm{m}$. ChRM directions are interpreted between 420 and $570{ }^{\circ} \mathrm{C}$ or 25-60 mT (for GO1), $330-570{ }^{\circ} \mathrm{C}$ or $30-70 \mathrm{mT}$ (GU1, GU2), $240-540{ }^{\circ} \mathrm{C}$ or $30-80 \mathrm{mT}$ (GU3), and $150-420{ }^{\circ} \mathrm{C}$ or $20-70 \mathrm{mT}$ (GU4), again suggesting magnetite as main carrier. Approximately half of the samples contained a high-T, or high coercivity reversed component alongside a strong, low-T or low-coercivity normal component that is close to the recent field and that we interpret as an overprint (Fig. 2-I). We interpreted the high-T components as ChRM directions if also the overprint direction was evident. The other half of the samples yielded normal directions that coincide with this overprint 


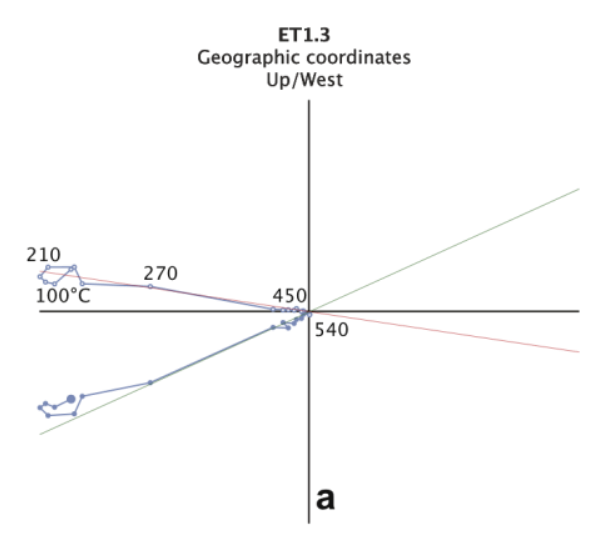

T02.4

Geographic coordinates

Up/West

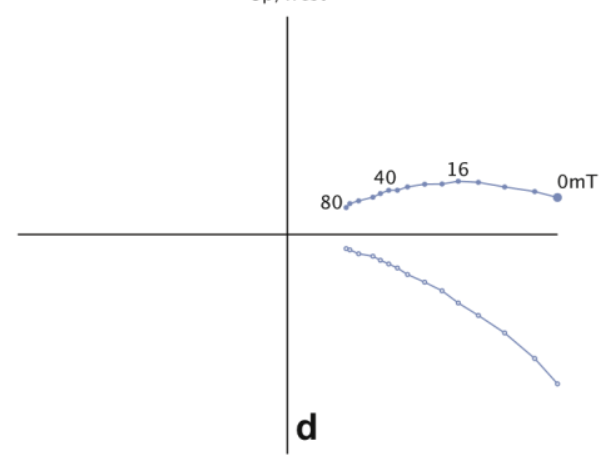

PC1.7

Geographic coordinates

Up/West

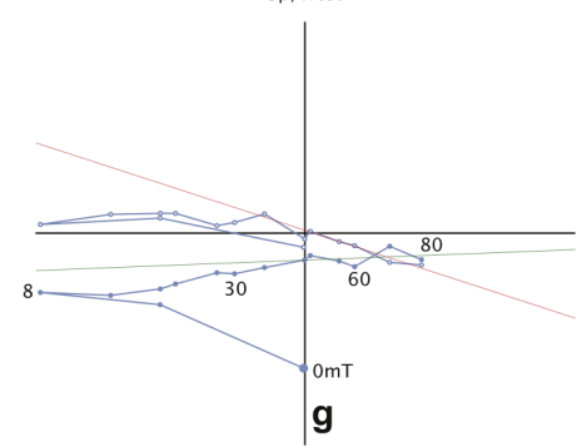

F01.8

Geographic coordinates

Up/West

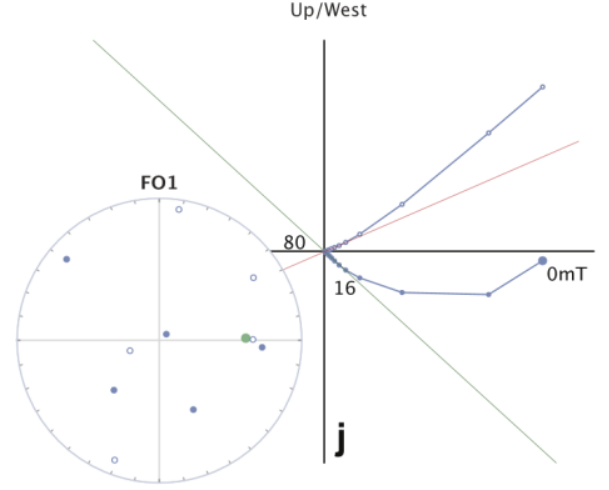

PC1.2

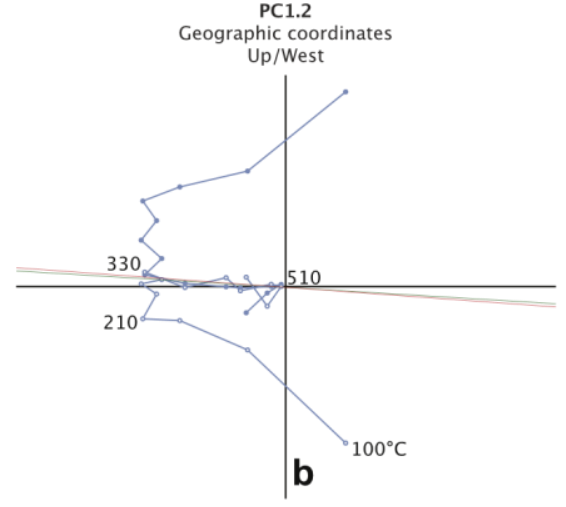

Geographic coordinates

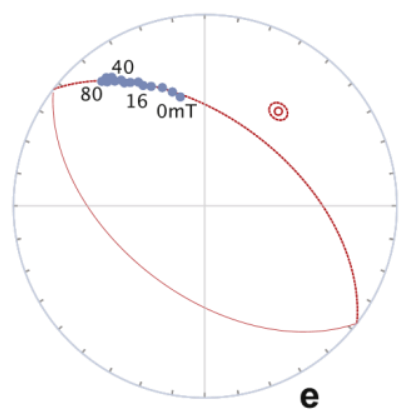

MI1.5

Geographic coordinates

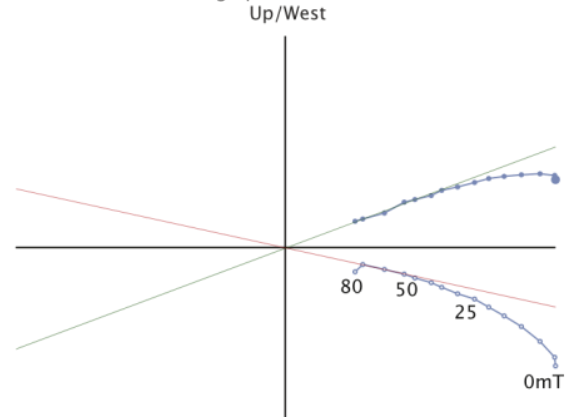

h

GU4.4

Geographic coordinates

Up/West

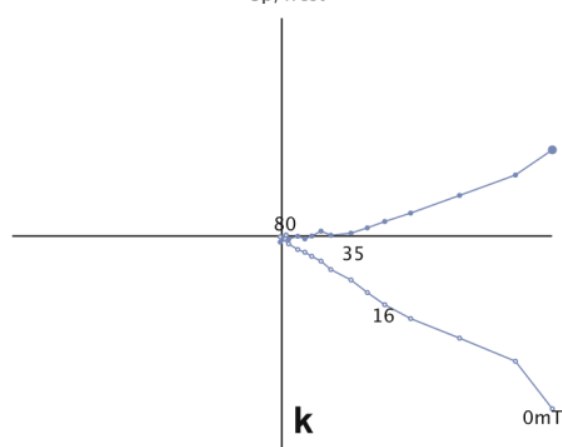

TO2.3

Geographic coordinates

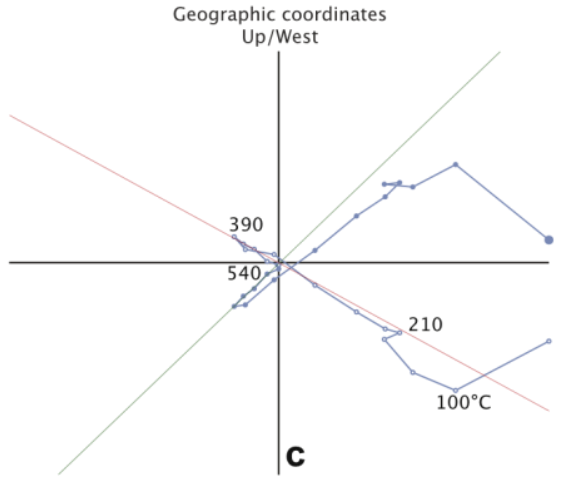

TO2

Geographic coordinates

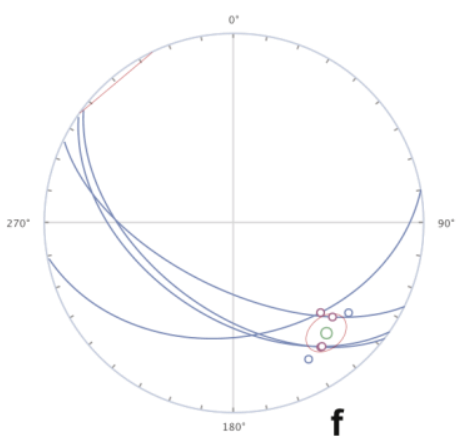

MI1.2

Geographic coordinates

Up/West

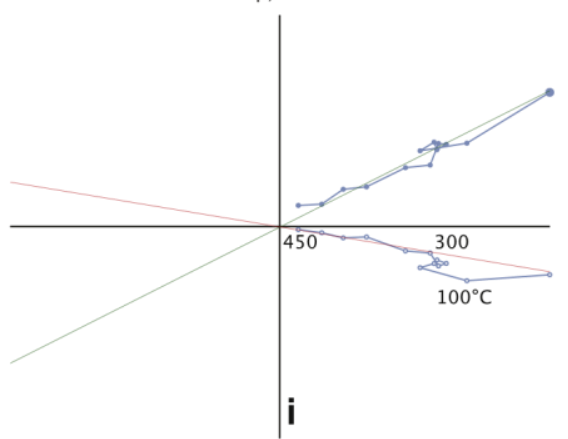

GU4.3

Geographic coordinates

Up/West

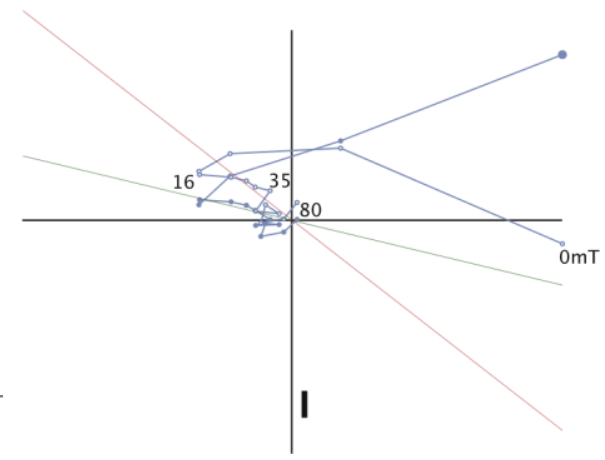

Fig. 2. Representative Zijderveld diagrams and great circle plots of the sampled lithologies of St. Barthélemy and île Fourchue. See text for further details. 


\section{Site means Eocene limestones Normalized directions Eocene limestones}

Geographic Coordinates

Geographic coordinates
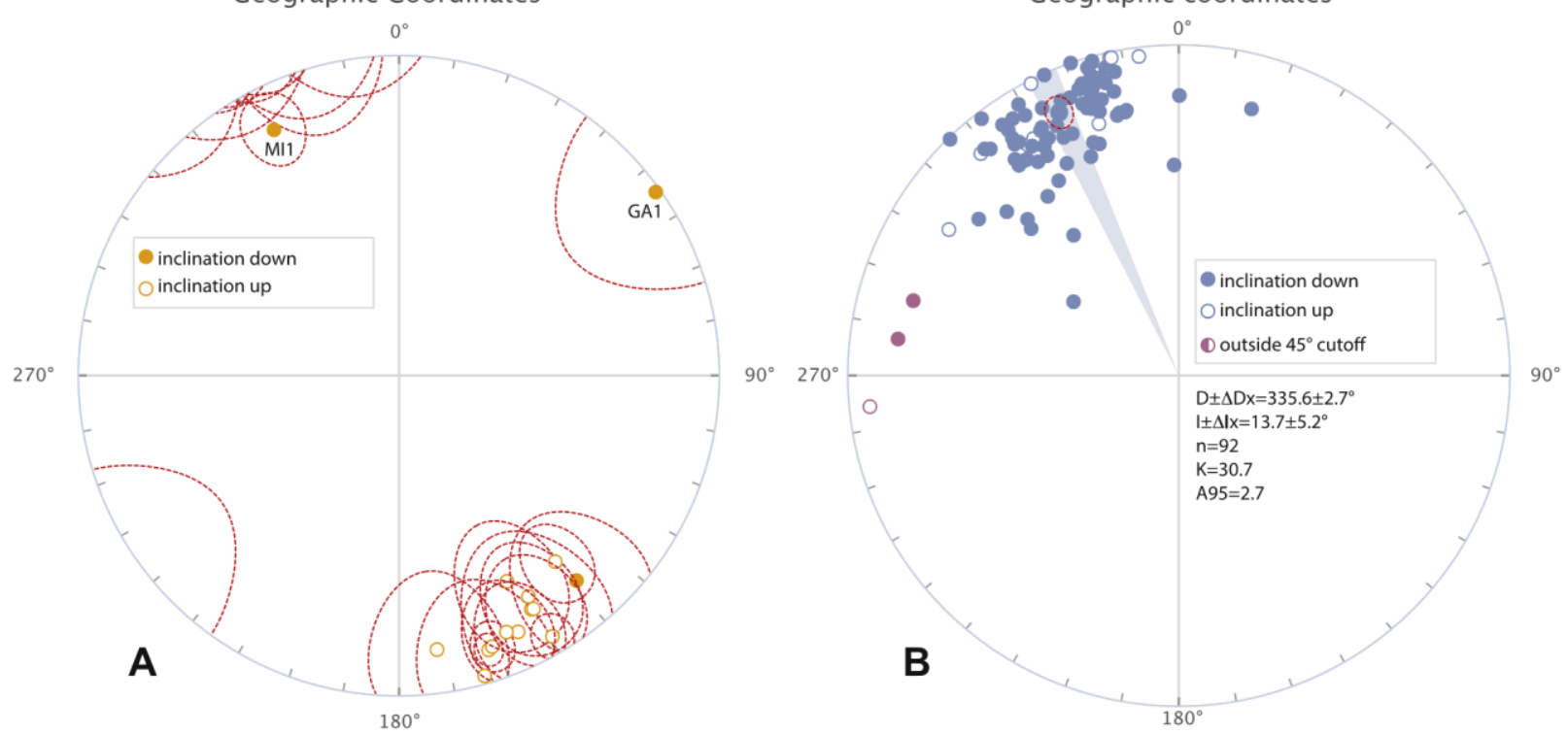

Site means Oligocene intrusions Normalized directions Oligocene intrusions Geographic coordinates

Geographic coordinates
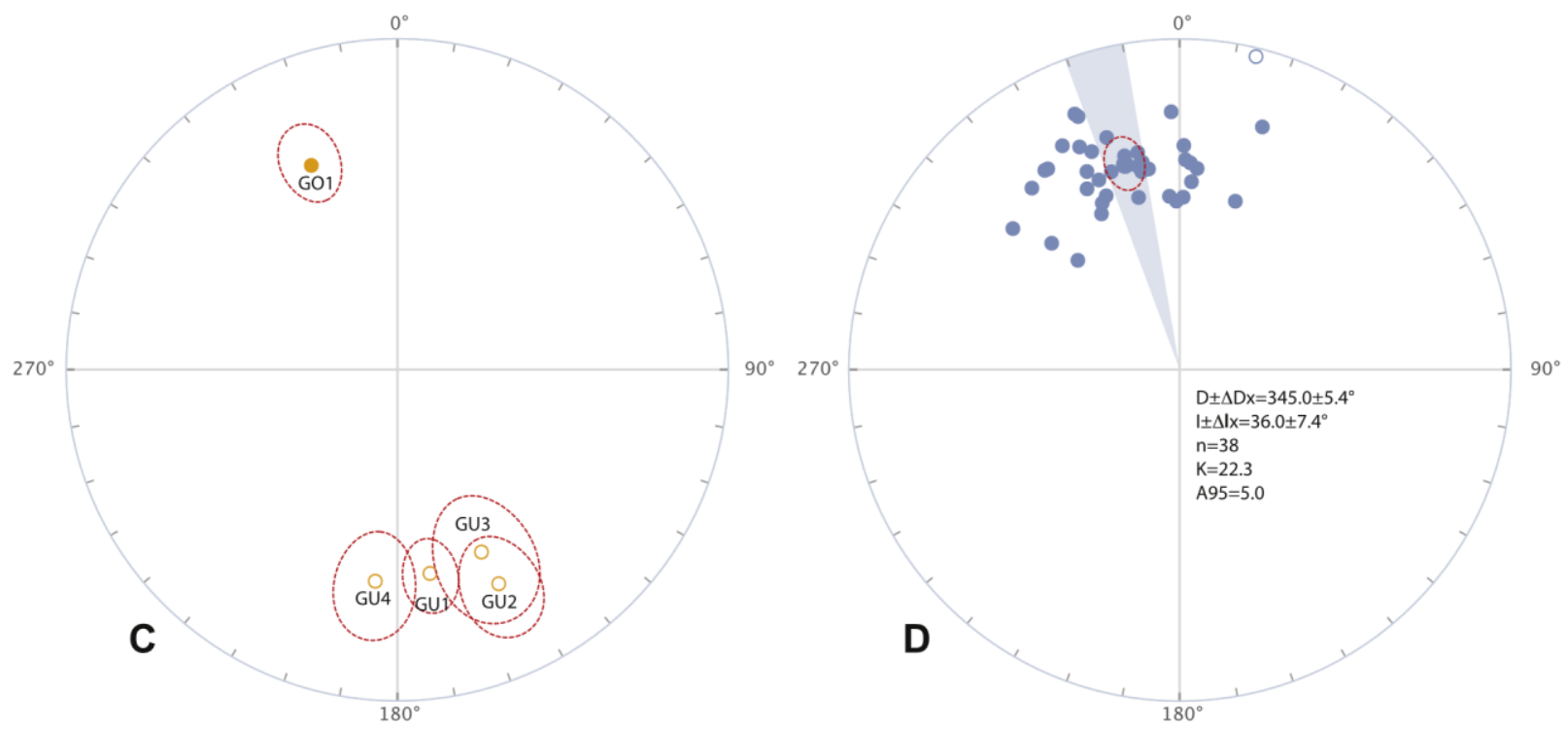

Fig. 3. Site averages ( $a, c)$ and ChRM directions of all samples from all sites $(b, d)$ of the remagnetized Eocene limestones (in geographic coordinates, i.e. not corrected for bedding tilt) and the Oligocene igneous intrusions of St. Barthelemy. 'Normalized' directions are all converted to normal polarity.

direction and from these samples, no ChRM was interpreted (Fig. 2k). The ChRM directions interpreted from the four GU sites have a reversed polarity, while site GO1 yields normal polarity (Fig. 4-c). When all directions are combined, these give an average direction of $D \pm \Delta D_{x}=345.0 \pm 5.4^{\circ}, I \pm \Delta I_{x}=36.0 \pm 7.4^{\circ}, n=38$, $\mathrm{K}=22.3$,

A95 = 5.0 (Fig. 3-d; Table 1). Averaging the five site averages leads to a statistically indistinguishable direction (Table 1).

\subsection{Interpretation of paleomagnetic results}

As outlined above, several sites were discarded from further analysis. Site GA1 yielded geologically meaningful results, but is rotated over some $80^{\circ}$ relative to all other sites, which we interpret as a local rotation that is not representative for the island at large. In addition, the sites from Eocene igneous rocks from île Fourchue and site PT1 from St. 
Barthélemy were interpreted to have been remagnetized due to lightning strikes. All other Eocene limestone sites yield mean directions with a normalized declination of $336 \pm 3^{\circ}$ and an inclination of $14 \pm 5^{\circ}$ (Fig. 3-b), corresponding to a paleolatitude of $\sim 7^{\circ} \mathrm{N}$. The single site of normal polarity MI 1 and the remaining reversed sites yields a positive bootstrapped reversal test (Tauxe, 2010) in geographic coordinates, and a negative test in tectonic coordinates. The normal Oligocene plutonic site GO1 combined with the reversed sites GU1-4 also yield a positive reversal test.

A regional fold test (of Tauxe and Watson (1994)) on both all Eocene limestone samples and site averages, is unequivocally negative (Fig. 4). This demonstrates post- or late syn-folding remagnetization. The average paleomagnetic direction from the Eocene limestones, in geographic coordinates (which only differs a few degrees from the average direction in tectonic coordinates) reveals a $25^{\circ}$

Bootstrapped foldtest

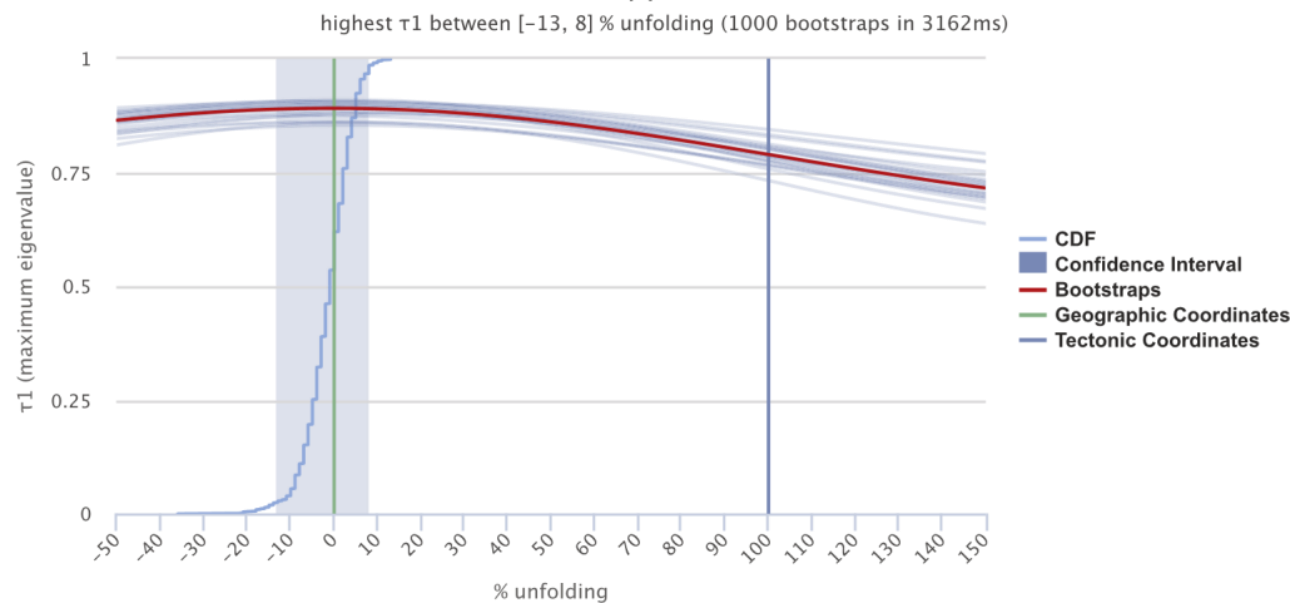

Fig. 4. Fold test of Tauxe and Watson (1994) performed on the ChRM directions interpreted from the Eocene limestones of St. Barthelemy. The fold test is clearly negative, signaling a post-folding remagnetization.

counterclockwise rotation relative to North (Fig. 3-b). The $A_{95}$ of the combined directions of all limestone sites $(n=92)$ fall within the

$A_{95 m i n}-A_{95-m a x}$ reliability envelope of Deenen et al. (2011), suggesting that remagnetization occurred over sufficiently long time period to have recorded paleosecular variation. Thus, despite the remagnetization, we interpret the magnetic direction as geologically meaningful and providing a minimum amount of rotation.

The paleomagnetic direction from the Oligocene igneous intrusions in western St. Barthélemy reveals a counterclockwise rotation of $\sim 15^{\circ}$ relative to North (Fig. 5) and the associated $A_{95}$ values also falls within the $A_{95 m i n}-A_{95-m a x}$ envelope of Deenen et al. (2011), suggesting that the scatter may be straightforwardly explained by paleosecular variation, and the average is useful for geological interpretation.

We note that the Oligocene intrusions yield a declination of $\sim 345^{\circ}, 10^{\circ}$ smaller than the regional declination derived from the limestones, and also the inclination differs by $\sim 10-15^{\circ}$. Although with larger error bar owing to the low number of samples (7), lower Miocene site PC1 yields similar results, both in geographic and in tectonic coordinates the magnetic direction obtained from the Oligocene igneous intrusions and lower Miocene site PC1 on the one hand, and the Eocene limestones, in geographic coordinates, on the other hand do not share a common true mean direction. From this we infer that the Oligocene intrusions were likely not responsible for the remagnetization. The maximum age of the remagnetized direction in the limestones is constrained by the age of the folding, which on eastern St. Barthélemy is dated by a 40 Ma Eocene igneous intrusion that pierces a thrust fault and associated folds (Legendre et al., 2018; Cornée et al., 2020). This renders the oldest possible age of the magnetization $\sim 40$ Myr. Because the folding pre-dates the Oligocene, and there is no evidence for significant tilting of the island after folding and remagnetization, we consider it therefore more likely that the remagnetization predates the Oligocene igneous activity and tentatively speculate that remagnetization occurred during the first igneous activity, around $40 \mathrm{Ma}$. This age should, however, be

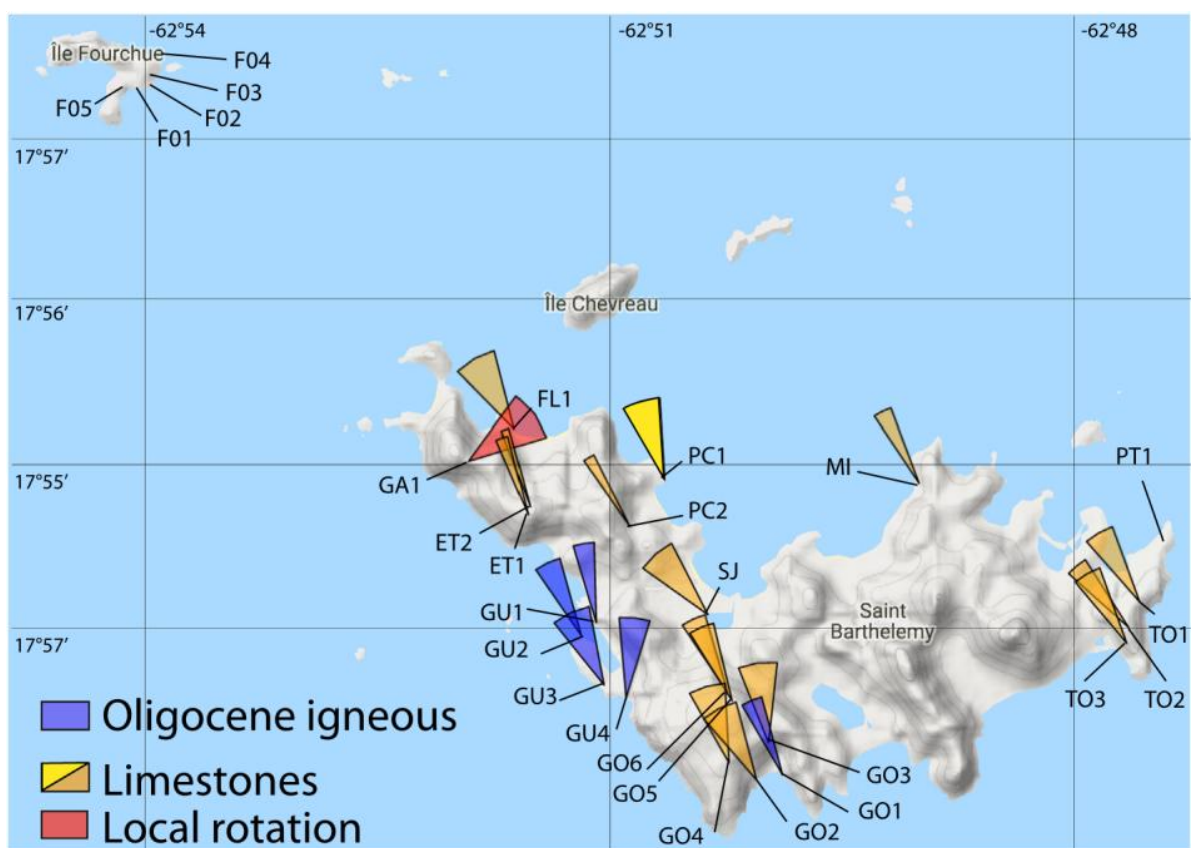
considered a maximum age, and a younger remagnetization age cannot be excluded.

Finally, the paleolatitudes predicted by our results for St Barthelemy are reasonably similar to those predicted for the Caribbean plate by the reference curves (Fig. 6). We do not interpret the deviations of up to

Fig. 5. Map showing the declination parachutes that represent the $95 \%$ confidence interval of the declination of the site averages. Yellow: limestone sites, red: site GA1 (interpreted to re-ect a local rotation), blue: Oligocene igneous sites. (For interpretation of the references to color in this figure legend, the reader is referred to the web version of this article.) 


\section{Paleomagnetic results St Barthelemy vs GAPWaP in Caribbean coordinates}
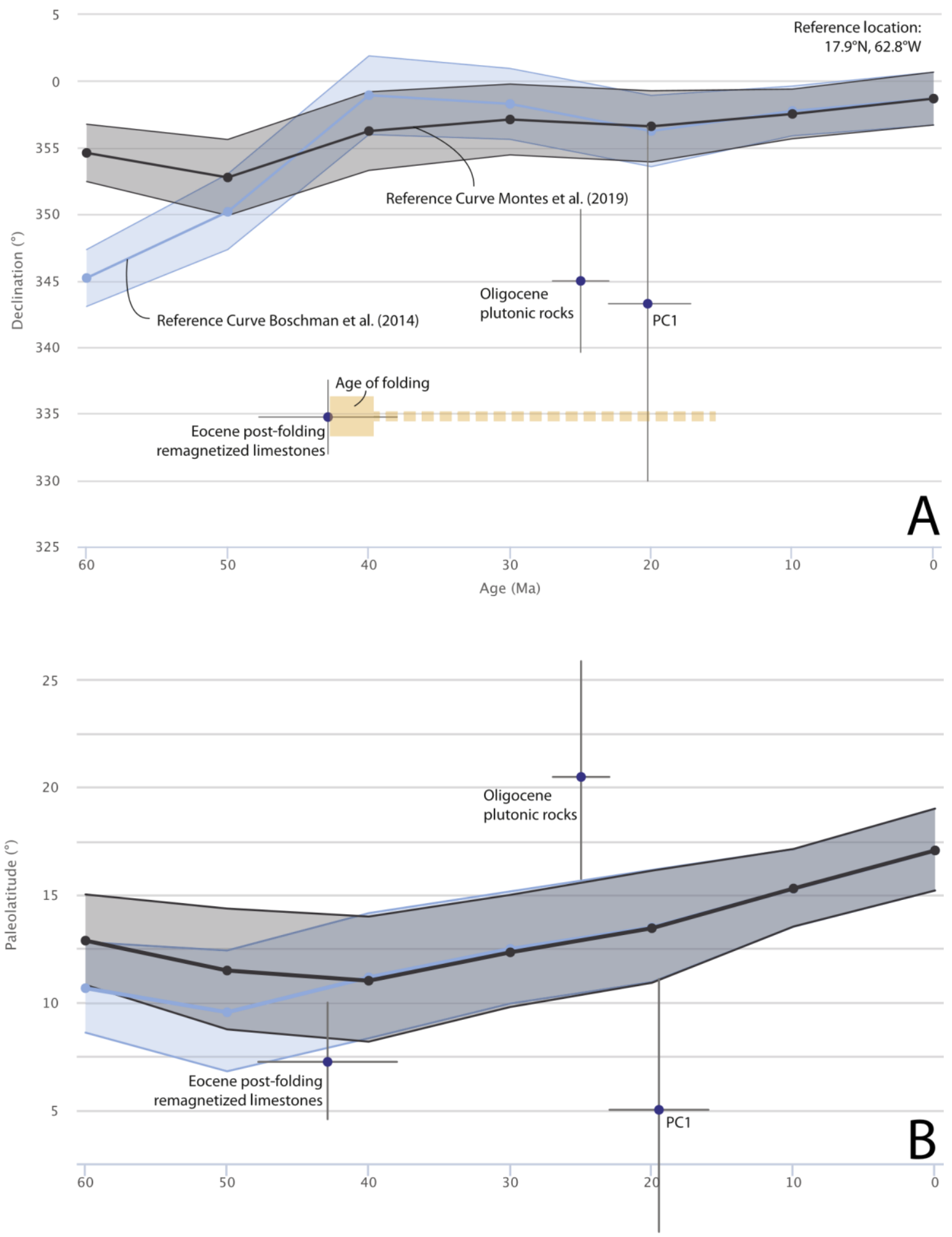

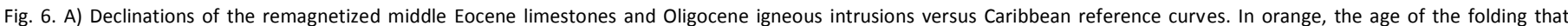

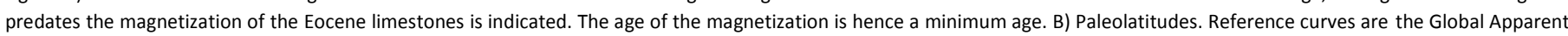
Polar Wander Path of Torsvik et al. (2012) rotated in Caribbean, or Venezuelan Basin, coordinates based on the reconstructions of

Boschman et al. (2014) and Montes et al. (2019b). 
$\sim 10^{\circ}$ between our results and the predicted curve as a signal of paleolatitudinal motion, but rather inherent scatter induced by secular variation that remains despite averaging paleomagnetic directions (see Deenen et al., 2011 for discussion) combined with unresolved minor tilts for the igneous rocks. Such tilts would not significantly influence the declination.

We compare the magnetic directions obtained in our study with the Global Apparent Polar Wander path of Torsvik et al. (2012) rotated into the coordinate

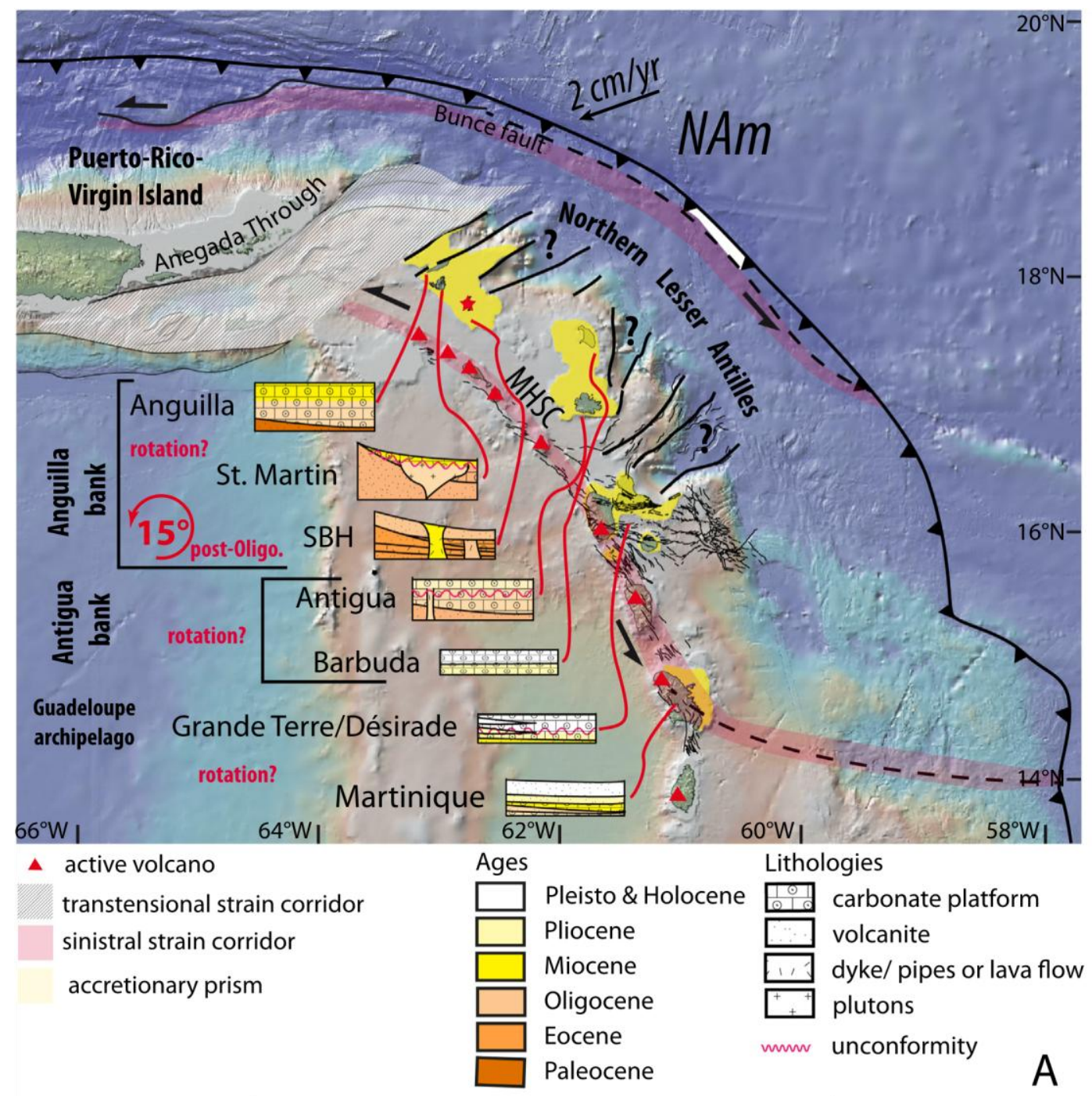

trench curvature accommodated by block rotation in the forearc

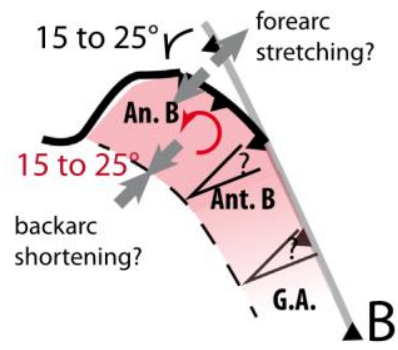

- Ante Eocene trench

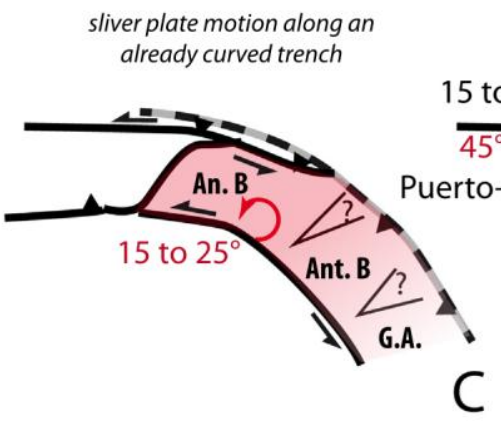

iver plate motion along a

Enhanced trench curvature

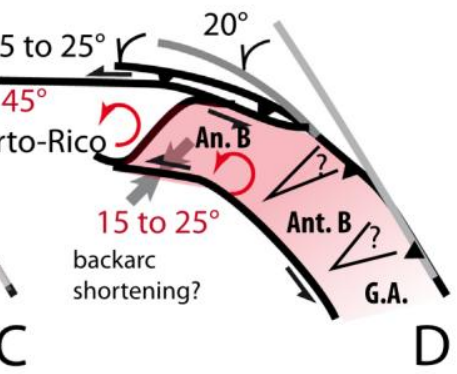

Present day trench

Northern Lesser Antilles Block

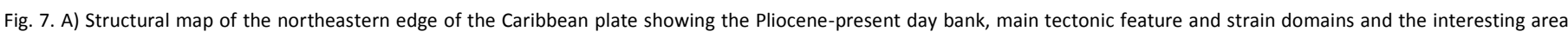

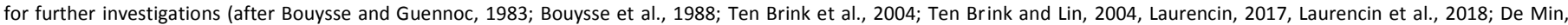

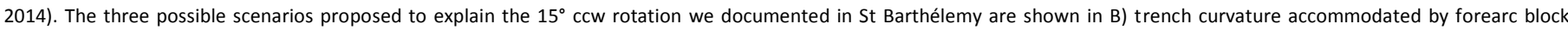

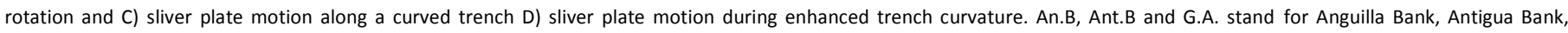
Guadeloupe Archipelago, respectively. (For interpretation of the references to color in this figure, the reader is

of the eastern Caribbean plate, using Euler poles from two recent kinematic restorations of the Caribbean region (Boschman

referred to the web version of this article.) 
et al., 2014; Montes et al., 2019b), following procedures explained in Li et al. (2017) (Fig. 6). We note that between the late Eocene and Oligocene, these reconstructions predict a $\sim 10^{\circ}$ counterclockwise rotation of the eastern Caribbean plate relative to the North. This may explain the declination difference between the remagnetized limestones and the Oligocene igneous rocks, assuming that remagnetization occurred around $40 \mathrm{Ma}$. We therefore conservatively interpret that the island of St. Barthélemy underwent a $\sim 15^{\circ}$ counterclockwise rotation relative to the Caribbean plate after the Oligocene. Furthermore, the lower Miocene site PC1 may suggest that rotation post-dates the early Miocene, but since we have only one paleomagnetic site with 7 samples of the lower Miocene, we leave further determination of the Neogene rotation history for future studies. Finally, a younger remagnetization age than the $45-40$ Ma estimated here of the Eocene limestones would signal a larger rotation of up to $25^{\circ}$.

\section{Insights on the forearc deformation history}

We now evaluate how a minimum $15^{\circ}$ counterclockwise PostOligocene rotation affecting St. Barthélemy island in the northern Lesser Antilles forearc (Fig. 7) may be tectonically explained. Strike slip deformation has been reported from the island but offsets and importance remain unknown (Fig. 1B; Legendre et al., 2018). Activation of such structures may result in differential block rotation, but the consistency of our dataset across the island and the absence of major fault zones renders an island-scale rotation more likely than rotation induced by local faults. It thus rather suggests that regional faults surrounding first-order blocks (tens $\mathrm{km}$ ) such as (i) the series of V-shaped grabens trending orthogonal-to-the-trench or (ii) the Anegada Through which may have accommodated the rotation documented here.

To the south and southeast of St. Barthélemy, three V-Shaped grabens may have accommodated counterclockwise rotation (see red question marks in Fig. 7). Direct geological or geophysical constraints on the kinematics of the V-shaped graben affecting the Lesser Antilles forearc are absent, but their steep scarp and deep bathymetry suggest extension, which may indicate intensifying curvature of the trench resulting in parallel-to-the-trench stretching (Feuillet et al., 2002). Scarce geological evidence puts some first-order constraints on the timing of tectonic activity along the V-shaped graben such as (i) gently tilted late Oligocene sedimentary rocks in Antigua and flat lying post-4.5 Ma series of Barbuda indicate that block tilting affected the Antigua bank between ca 30 and ca 4.5 Ma (Mascle and Westercamp, 1983; Donahue et al., 1985); and (ii) the southernmost V-shaped graben, just northeast of La Désirade island is sealed by the Zancléan to Calabrian Grande Terre carbonate platform (oldest age known: $4.5 \mathrm{Ma}$; Cornée et al., 2012; Münch et al., 2014) suggesting that motion along these structures is pre-4.5 Ma (Fig. 7A).

To the northwest, the Anegada Trough is the most likely candidate to have accommodated significant deformation that may accommodate regional rotation. Also, this trough appears to have ceased accommodating strain some 4.5 Ma (Chaytor and ten Brink, 2015). Southwestward, the Montserrat Harvers Strain Corridor is the most likely candidate to have accommodated deformation, but its activity is only since known since late Pliocene (Feuillet et al., 2011).

As we ruled out the possibility of strike-slip induced rotated blocks at island scale, backed up by the consistency of declination across the island, our observations allow for three end-member regional mechanisms affecting the Lesser Antilles forearc and explaining the rotation of St. Barthélemy.

(i) the northeastern Caribbean forearc rotated as a single block over atleast $15^{\circ}$, and perhaps up to $25^{\circ}$ counterclockwise relative to the stable Caribbean plate interior after the Oligocene and early Miocene (Fig. 7B). This may have led to the opening of V-shaped grabens in the forearc but requires contraction between the Caribbean plate interior and the NE Caribbean forearc. There is currently no evidence for the latter.

(ii) the rotation may represent a forearc sliver motion around a previously curved trench and transform fault between the forearc sliver and the Caribbean plate interior (Fig. 7C). This may be consistent with interpretations of the MHSC, but requires motion over several hundreds of kilometers. Such a displacement is currently not documented. As a whole, considering a progressive curvature born during Cenozoic does not fit with available data. At present day, the observation that the Lesser Antilles trench is curved by $22^{\circ}$ to the west (counterclockwise) along the Anguilla bank (Fig. $7 \mathrm{~A}$ ), similar to the amount of rotation recorded in St. Barthélemy, may argue for this scenario in which rotation is accommodated by motion of a forearc sliver around an a priori curved trench (Fig. 7C).

(iii) the rotation may represent enhanced trench curvature, the amountof motion needed to accommodate this rotation being directly block-size-dependent (Fig. 7D). One would expect that the amount of rotation increases across every V-shaped basin. A paleomagnetic study of presumed Oligocene rocks exposed in Antigua, coupled with marine geophysics across the three V-shaped grabens would test this prediction (Fig. 7A). Such forearc block rotation requires significant shortening in the Oligo-Miocene Lesser Antilles backarc, between the NE Caribbean forearc and the Caribbean plate interior. Such shortening would require a (distributed) equivalent of the Muertos Trough, to which the Montserrat-Harvers strain corridor may belong. Our dataset shows that the forearc cannot only have undergone radial extension accommodated by trench-perpendicular V-shaped grabens (Feuillet et al., 2002, 2011): to explain our data, this needs to have gone hand in hand with upper plate shortening in the more interior domains. If this scenario is valid, the amount of rotation will be at first order consistent across the islands of the NE Caribbean region. To the west of the Anegada Trough, preliminary paleomagnetic results from the Puerto Rico-Virgin Islands blocks were interpreted to reveal $>45^{\circ}$ of post-Eocene counterclockwise rotation, $25^{\circ}$ of which occurred between 11 and 4.5 Ma (Flink and Harrison, 1971; Van Fossen et al., 1989; Reid et al., 1991). These data are based on few sites, and the differences between sites may reflect local rotation or rotation through time. Nevertheless, if these islands recorded $45^{\circ}$ rotation, then the scenario of forearc sliver motion around a curved trench is not, or not only, valid.

6. Conclusions

Our pioneering study on Eocene and Oligocene intrusive rocks and post-folding remagnetized Eocene limestones suggests that at least $15^{\circ}$ and perhaps up to $25^{\circ}$ of counterclockwise rotation relative to the stable Caribbean plate interior affected the island of St. Barthélemey in the Lesser Antilles forearc sometime after the Oligocene. We identify three end-member scenarios that may explain this rotation of the Lesser Antilles forearc: (i) post-Eocene trench curvature, (ii) motions of an inherited forearc sliver around an a priori curved trench or (iii) enhancement of the trench curvature in the course of Eocene. The second or last scenario are supported by current observations and datasets. However, we consider our study of St Barthélemy a starting point for a paleomagnetic evaluation of the deformation history of the Lesser

Antilles forearc. 
Acknowledgments, samples, and data

MP acknowledges the ObliSUB project granted by INSU TelluSSYSTER 2017. MP, PM, JJC, JLL and JFL acknowledge the GAARAnti project ANR-17-CE31-0009. DJJvH acknowledges NWO VICl grant 865.17.001. The paleomagnetic dataset is available Open Science Framework via the following link: https://osf.io/p4svt. We thank the reviewers Camilo Montes and Manuel that provided fruitful comments that improved our manuscript.

\section{References}

Baird, A.F., Kendall, J.M., Sparks, R.S.J., Baptie, B., 2015. Transtensional deformation of Montserrat revealed by shear wave splitting. Earth Planet. Sci. Lett. $425,179-186$. Boschman, L.M., van Hinsbergen, D.J.J., Torsvik, T.H., Spakman, W., Pindell, J.L., 2014. Kinematic reconstruction of the Caribbean region since the Early Jurassic. Earth Sci. Rev. 138, 102-136.

Boschman, L.M., van der Wiel, E., Flores, K.E., Langereis, C.G., van Hinsbergen, D.J., 2019. The Caribbean and Farallon plates connected: constraints from stratigraphy and paleomagnetism of the Nicoya Peninsula, Costa Rica. Journal of Geophysical Research: Solid Earth 124 (7), 6243-6266.

Bouysse, P., Guennoc, P., 1983. Donnees sur la structure de l'arc insulaire desPetites Antilles: Entre St Lucie et Anguilla. Mar. Geol. 53, $131-166$.

Bouysse, P., Westercamp, D., 1990. Subduction of Atlantic aseismic ridges and Late Cenozoic evolution of the Lesser Antilles island arc. Tectonophysics 175 (4), 349-380.

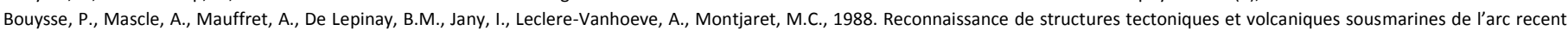
des Petites Antilles (Kick'em Jenny, Qualibou, Montagne Pelee, nordouest de la Guadeloupe). Mar. Geol. 81 (1-4), 261-287.

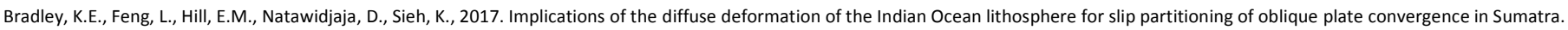
Journal of Geophysical Research: Solid Earth 122, 572-591.

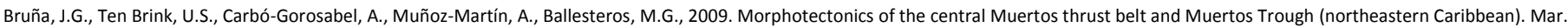
Geol. 263 (1-4), 7-33.

Butler, R.F., 1992. Paleomagnetism: magnetic domains to geologic terranes. 319 Blackwell Scientific Publications, Boston.

Byrne, D.B., Suarez, G., McCann, W.R., 1985. Muertos Trough subduction-microplate tectonics in the northern Caribbean? Nature 317 (6036), 420.

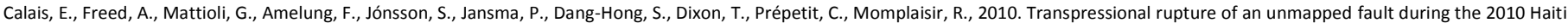
earthquake. Nat. Geosci. 3 (11), 794.

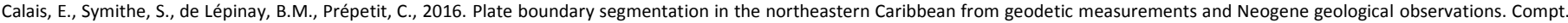
Rendus Geosci. 348 (1), 42-51.

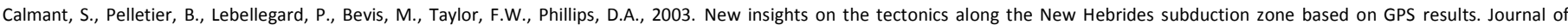
Geophysical Research: Solid Earth 108 (B6).

Case, J.E., Holcombe, T.L., 1980. Geologic-Tectonic Map of the Caribbean Region (No. 1100).

Chaytor, J.D., ten Brink, U.S., 2015. Event sedimentation in low-latitude deep-water carbonate basins, Anegada passage, northeast Caribbean. Basin Res. 27 (3), $310-335$.

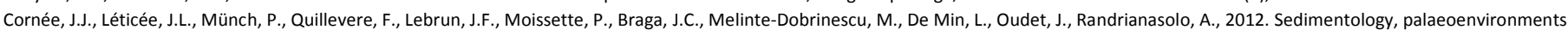
and biostratigraphy of the Pliocene-Pleistocene carbonate platform of Grande-Terre (Guadeloupe, Lesser Antilles forearc). Sedimentology 59 (5), 1426-1451.

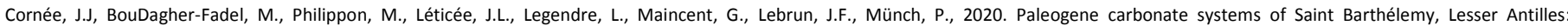
stratigraphy and general organization. Newsl. Stratigr (In press).

Curray, J.R., 2005. Tectonics and history of the Andaman Sea region. J. Asian Earth Sci. 25, 187-232.

De Min, L., 2014. Sismo-stratigraphie multi-échelles d'un bassin d'avant-arc: le bassin de Marie-Galante, Petites Antilles. Doctoral dissertation. Antilles-Guyane, pp. 340.

De Min, L., Lebrun, J.F., Cornée, J.J., Münch, P., Léticée, J.L., Quillevere, F., MelinteDobrinescu, M., Randrianasolo, A., Marcaillou, B., Zami, F., 2015. Tectonic and sedimentary architecture of the Karukéra spur: a record of the Lesser Antilles fore-arc deformations since the Neogene. Mar. Geol. 363, 15-37.

Deenen, M.H., Langereis, C.G., van Hinsbergen, D.J., Biggin, A.J., 2011. Geomagnetic secular variation and the statistics of palaeomagnetic directions. Geophys. J. Int. 186 (2), 509-520.

Donahue, J., Brasier, M., Watters, D.R., 1985. Barbuda, West Indies: a record of seal level change since Pliocene time. Geol. Soc. Am., Abstr. Programs; (United States) 17 (CONF-8510489-).

Dorel, J., 1981. Seismicity and seismic gap in the Lesser Antilles arc and earthquake hazard in Guadeloupe. Geophys. J. R. Astron. Soc. 67 (3), $679-695$.

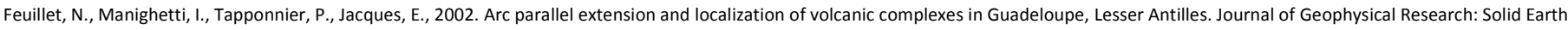
107 (B12), ETG-3.

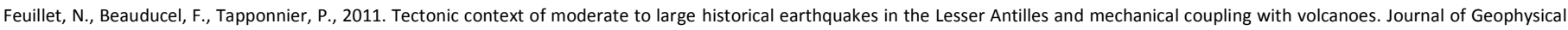
Research: Solid Earth 116 (B10).

Fisher, R.A., 1953. Dispersion on a sphere. Proceedings of the Royal Society of London. Series A. Mathematical and Physical Sciences 217 (1130), $295-305$.

Flink, Harrison, 1971. Paleomagnetic investigations of selected lava units on Puerto Rico, (abs). In: Memorias de VI Confierencia Geologica del Caribe, Margarita, Venezuela, pp. 379.

Grindlay, N.R., Hearne, M., Mann, P., 2005. High risk of tsunami in the northern Caribbean. Eos, Transactions American Geophysical Union 86 (12), $121-126$.

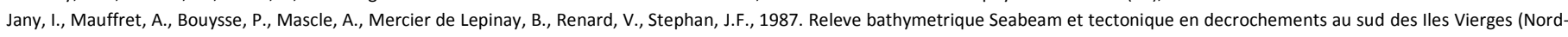
Est Caraibes). Comptes rendus de l'Académie des sciences. Série 2, Mécanique, Physique, Chimie, Sciences de l'univers. Sci. Terre 304 (10), 527-532.

Jany, I., Scanlon, K.M., Mauffret, A., 1990. Geological interpretation of combined Seabeam, Gloria and seismic data from Anegada Passage (Virgin Islands, north Caribbean). Mar. Geophys. Res. 12 (3), 173-196.

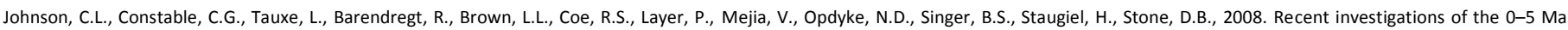
geomagnetic field recorded by lava flows. Geochem.

Geophys. Geosyst. 9 (4), Q04032.

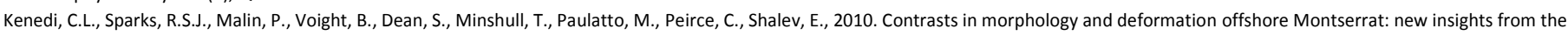
SEA-CALIPSO marine cruise data. Geophys. Res. Lett. 37 (19).

Kirschvink, J.L., 1980. The least-squares line and plane and the analysis of palaeomagnetic data. Geophys. J. R. Astron. Soc. 62 (3), $699-718$.

Kissel, C., Laj, C., 1988. The Tertiary geodynamical evolution of the Aegean arc: a paleomagnetic reconstruction. Tectonophysics 146 (1-4), 183-201.

Koymans, M.R., Langereis, C.G., Pastor-Galán, D., van Hinsbergen, D.J.J., 2016. Paleomagnetism. Org: An Online Multi-platform Open Source Environment for Paleomagnetic Data Analysis.

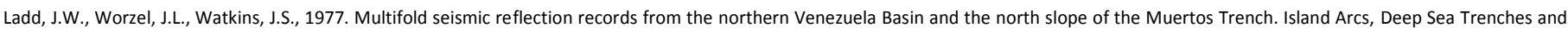
Back-Arc Basins 1, 41-56.

Laó-Dávila, D.A., 2014. Collisional zones in Puerto Rico and the northern Caribbean. J. S.

Am. Earth Sci. 54, 1-19.

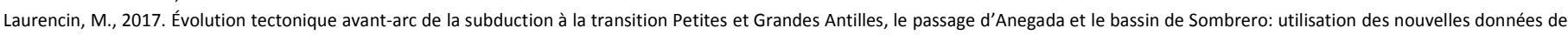
la campagne Antithesis.

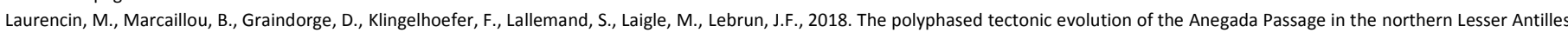
subduction zone. Tectonics 36 (5), 945-961.

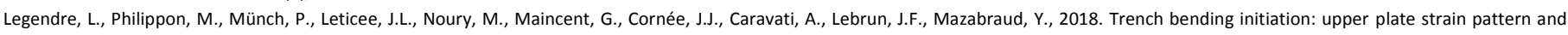
volcanism. Insights from the Lesser Antilles Arc, St.

Barthelemy Island, French West Indies. Tectonics 37 (9), 2777-2797. 


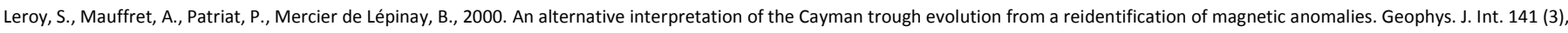
539-557.

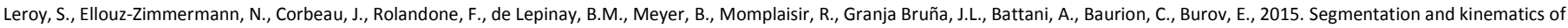
the North America-Caribbean plate boundary offshore Hispaniola. Terra Nova 27 (6), 467-478.

Li, S., Advokaat, E.L., van Hinsbergen, D.J.J., Koymans, M., Deng, C., Zhu, R., 2017.

Paleomagnetic constraints on the Mesozoic-Cenozoic paleolatitudinal and rotational history of Indochina and South China: review and updated kinematic reconstruction. Earth Sci. Rev. 171, $58-77$.

López, A.M., Stein, S., Dixon, T., Sella, G., Calais, E., Jansma, P., Weber, J., LaFemina, P., 2006. Is there a northern Lesser Antilles forearc block? Geophys. Res. Lett. 33 (7).

Mann, P., Burke, K., 1984. Neotectonics of the Caribbean. Rev. Geophys. 22 (4), 309-362.

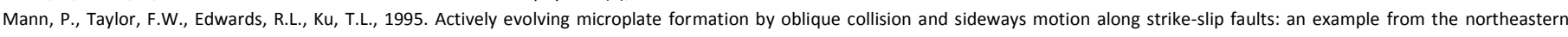
Caribbean plate margin. Tectonophysics 246 (1-3), 1-69.

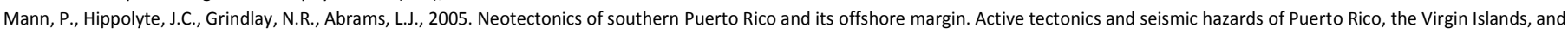
offshore area. $\quad 385,173-214$.

Mascle, A., Westercamp, D.A., 1983. Géologie d'Antigua, Petites Antilles. Bulletin Société géologique de France 7 (6), 855-866 t.XXV.

Masson, D.G., Scanlon, K.M., 1991. The neotectonic setting of Puerto Rico. Geol. Soc. Am. Bull. 103 (1), 144-154.

Mauffret, A., Jany, I., 1990. Collision et tectonique d'expulsion le long de la frontiere Nord-Caraibe. In: Oceanologica Acta. 97-116 (Special issue) ISSN 0399-1784; e-ISSN 1878-4143.

McCabe, R., 1984. Implications of paleomagnetic data on the collision related bending of island arcs. Tectonics 3 (4), 409-428.

McFadden, P.L., McElhinny, M.W., 1988. The combined analysis of remagnetization circles and direct observations in palaeomagnetism. Earth Planet. Sci. Lett. 87 (1-2), 161-172.

Molnar, P., Sykes, L.R., 1971. Plate tectonics in the Hispaniola area: discussion. Geol. Soc. Am. Bull. $82(4), 1123-1126$.

Montes, C., Rodriguez-Corcho, A.F., Bayona, G., Hoyos, N., Zapata, S., Cardona, A., 2019a. Continental margin response to multiple arc-continent collisions: the northern Andes-Caribbean margin. Earth Sci. Rev. 198, 102903. https://doi.org/10.1016/j. earscirev.2019.102903.

Montes, C., Rodriguez-Corcho, A.F., Bayona, G., Hoyos, N., Zapata, S., Cardona, A., 2019b. GPlates dataset for the tectonic reconstruction of the Northern AndesCaribbean Margin. Data in brief 25, 104398.

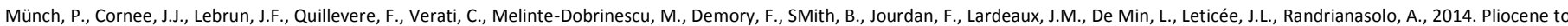
Pleistocene vertical movements in the forearc of the Lesser Antilles subduction: insights from chronostratigraphy of shallow-water carbonate platforms (Guadeloupe archipelago). J. Geol. Soc. $171(3), 329-341$

Philippon, M., Corti, G., 2016. Obliquity along plate boundaries. Tectonophysics 693, 171-182.

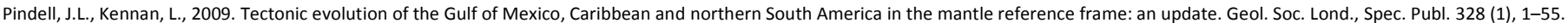

Plunder, A., Thieulot, C., Van Hinsbergen, D.J., 2018. The effect of obliquity on temperature in subduction zones: insights from 3-D numerical modeling. Solid Earth 9 (3), 759-776.

Raussen, S., Lykke-Andersen, H., Kuijpers, A., 2013. Tectonics of the Virgin Islands basin, north eastern Caribbean. Terra Nova 25 (3), $252-257$.

Reid, J.A., Plumley, P.W., Schellekens, J.H., 1991. Paleomagnetic evidence for late Miocene counterclockwise rotation of north coast carbonate sequence, Puerto Rico. Geophys. Res. Lett. 18 (3), 565-568.

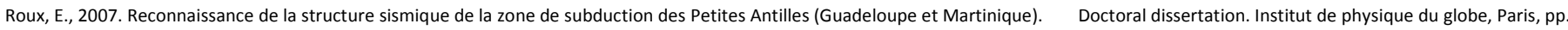
249.

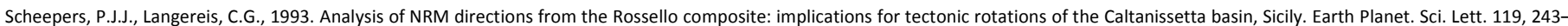
258.

Spakman, W., Chertova, M.V., van den Berg, A., van Hinsbergen, D.J., 2018. Puzzling features of western Mediterranean tectonics explained by slab dragging. Nat. Geosci. 11 (3), 211.

Speed, R.C., Larue, D.K., 1991. Extension and transtension in the plate boundary zone of the northeastern Caribbean. Geophys. Res. Lett. 18 (3), $573-576$.

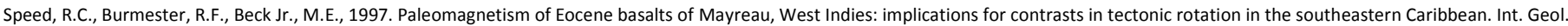
Rev. 39, 82-95.

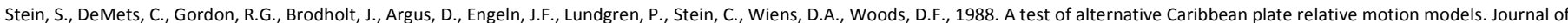
Geophysical Research: Solid Earth 93 (B4), 3041-3050.

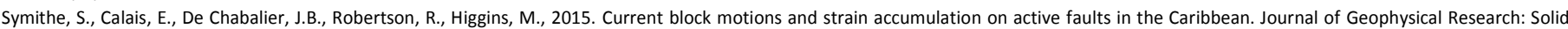
Earth 120 (5), 3748-3774.

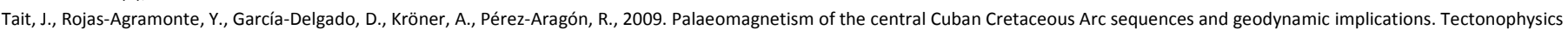
470, 284-297.

Tauxe, L., 2010. Essentials of Paleomagnetism. Univ of California Press.

Tauxe, L., Watson, G.S., 1994. The fold test: an Eigen analysis approach. Earth Planet. Sci. Lett. 122 (3-4), 331-341.

Ten Brink, U., Lin, J., 2004. Stress interaction between subduction earthquakes and forearc strike-slip faults: modeling and application to the northern Caribbean plate boundary. Journal of Geophysical Research: Solid Earth 109 (B12).

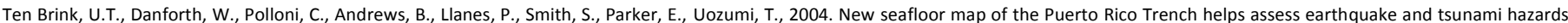
Eos, Transactions American Geophysical Union 85 (37), 349-354.

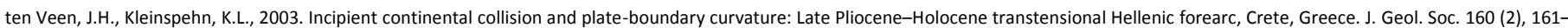
181.

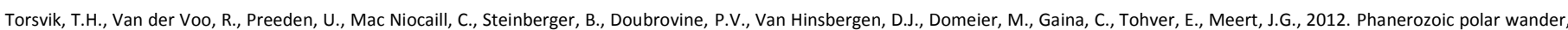
palaeogeography and dynamics. Earth Sci. Rev. 114 (3-4), 325-368.

Van Benthem, S., Govers, R., 2010. The Caribbean plate: pulled, pushed, or dragged? Journal of Geophysical Research: Solid Earth 115 (B10).

van Benthem, S., Govers, R., Spakman, W., Wortel, R., 2013. Tectonic evolution and mantle structure of the Caribbean. Journal of Geophysical Research: Solid Earth 118 (6), 3019-3036.

van Benthem, S., Govers, R., Wortel, R., 2014. What drives microplate motion and deformation in the northeastern Caribbean plate boundary region? Tectonics 33 (5), $850-873$.

Van Fossen, M.C., Channell, J.E., Schellekens, J.H., 1989. Paleomagnetic evidence for Tertiary anticlockwise rotation in southwest Puerto Rico. Geophys. Res. Lett. 16 (8), 819-822.

van Hinsbergen, D.J.J., Vissers, R.L., Spakman, W., 2014. Origin and consequences of western Mediterranean subduction, rollback, and slab segmentation. Tectonics 33, 393-419.

van Hinsbergen, D.J.J., Torsvik, T., Schmid, S.M., Matenco, L., Maffione, M., Vissers, R.L.M., Gürer, D., Spakman, W., 2020. Orogenic architecture of the Mediterranean region and kinematic reconstruction of its tectonic evolution since the Triassic.

Gondwana Res. 81, 79-229.

Vincenz, S., Dasgupta, S., 1978. Paleomagnetic study of some Cretaceous and Tertiary rocks on Hispaniola. Pure Appl. Geophys. 116, 1200-1210.

Vogt, P.R., Lowrie, A., Bracey, D.R., Hey, R.N., 1976. Subduction of aseismic oceanic ridges: Effects on shape, seismicity, and other characteristics of consuming plate boundaries: Geological Society of America Special Paper. $\quad 17259 \mathrm{p}$.

Wallace, L.M., McCaffrey, R., Beavan, J., Ellis, S., 2005. Rapid microplate rotations and backarc rifting at the transition between collision and subduction. Geology 33 (11), 857-860.

Wallace, L.M., Ellis, S., Mann, P., 2009. Collisional model for rapid fore-arc block rotations, arc curvature, and episodic back-arc rifting in subduction settings. Geochem.

Geophys. Geosyst. 10 (5). 


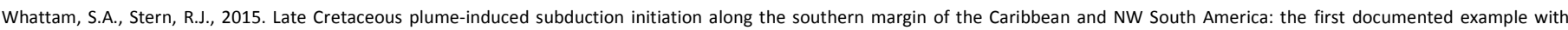
implications for the onset of plate tectonics. Gondwana Res. 27 (1), 38-63.

Zijderveld, J.D.A., 1967. The natural remanent magnetizations of the Exeter volcanic traps (Permian, Europe). Tectonophysics 4 (2), $121-153$. 